Article

\title{
Design Guidelines Developed from Environmental Assessments: A Design Tool for Resource-Efficient Products
}

\author{
Siri Willskytt ${ }^{1, *(1)}$ and Sergio A. Brambila-Macias ${ }^{2}$ \\ 1 Department of Technology Management and Economics, Division of Environmental Systems Analysis, \\ Chalmers University of Technology, SE-412 96 Gothenburg, Sweden \\ 2 Department of Management and Engineering, Division of Environmental Technology and Management, \\ Linköping University, SE-58183 Linköping, Sweden; sergio.brambila@liu.se \\ * Correspondence: siri.willskytt@chalmers.se
}

Received: 8 May 2020; Accepted: 11 June 2020; Published: 17 June 2020

\begin{abstract}
The circular economy provides a potential solution to the take-make-dispose model of resource use that currently characterizes the economy. Guidelines for the circular economy often consist of prioritized lists of measures to achieve resource efficiency. However, for the purpose of designing products, such general prioritizations of measures are less useful. Instead, the tool developed in this study is based on learnings from numerous life cycle assessments and provides design recommendations for the improved resource efficiency of products based on product characteristics. The tool includes measures over the whole lifecycle of different products that lead to improved resource efficiency. The tool also demonstrates how different product types, such as different varieties of durable and consumable products, can become more resource-efficient and when trade-offs occur over the lifecycle of a product. The tool was tested in a design case where its usefulness and usability were evaluated using a comparative life cycle assessment and a questionnaire. The evaluation shows the tool is informative and provides design suggestions that lead to improved resource efficiency. The tool is considered usable and could be implemented in design practice.
\end{abstract}

Keywords: design guidelines; circular economy; resource efficiency; durable products; consumable products; design tool; life cycle assessment

\section{Introduction}

Resource use and the associated generation of waste and pollution from human activities have been concerns for several decades (see for instance Meadows, et al. [1]). The most recent response to this challenge is the idea of the circular economy (CE), defined by some as a decoupling of economic growth from resource consumption by keeping materials at their highest quality in a closed loop [2]. Many guidelines and frameworks have been introduced within this concept, presenting prioritized lists of principles and measures for achieving a $\mathrm{CE}[3,4]$, such as the reusing, repairing, remanufacturing, and recycling of products. Reike, et al. [5] reviewed $69 \mathrm{CE}$ papers on measures and found that almost $60 \%$ recommend the use of these measures in a clear hierarchy.

Many circular design methods have been suggested in recent years (see for example [6,7]). For the purpose of this study, the term "method" includes methods, tools, and frameworks found in the literature. Despite this growing number of methods, some limitations remain. For instance, design guidelines for the CE are often presented with prioritized lists of design measures [8-10]. Byggeth and Hochschorner [11] argued that the ranking of strategies in design tools is important for facilitating decisions. However, other research showed that these ranking lists of measures are not useful since they do not consider real-world circumstances, such as low collection rates in recycling, losses in 
remanufacturing, and other system insufficiencies [12]. Measures can be interdependent [13], meaning that several measures work in sequence or parallel, which decreases the meaningfulness of their ranking. Instead, the characteristics of products, such as lifespan, material content, and whether the product requires energy during use, were argued to determine the suitability and outcome of a measure [14,15]. This means that not all measures are applicable to all product types. For this reason, design methods are needed to inform relevant design guidelines based on product characteristics [15].

Although it has been argued that it is important to be aware of trade-offs in the early design stages of a product [11], reports of the trade-offs of different CE measures and products are scarce in design tools [5]. Limitations exist on which design measures are considered in the design methods. For instance, whether design considerations are included that aim to change user behavior, beyond emotional durability. Ceschin and Gaziulusoy [16] reviewed design for sustainability (DfS) literature and concluded that DfS contributes to the $\mathrm{CE}$, but the notion of the $\mathrm{CE}$ generally has a limited emphasis on user practice and behavior [16,17]. Additionally, design tools vary in their coverage of product types, from a focus on certain product types, mainly durable products [18-20], to the inclusion of all types [10]. Similarly, as pointed out by Telenko, et al. [21] (p. 2), "The difficulty with Design for Environment (DfE) principles and guidelines is that they are scattered throughout the literature, in various forms and levels of abstraction, and often with focused emphases on specific life-cycle stages, products, or industries".

The literature reports that most design methods and tools are not applied in professional design practice [22]. Consequently, design tools have focused on making the tools more useful [23]. Guidance on how to address both usefulness and usability [24] and suggested characteristics for tools that are easy to use have been considered in the research [25]. Despite these efforts, continued low uptake in industry seems to be an issue [26]. Dickson and Stolterman [27] suggested increasing the usability of methods by including the user in the design of the tool by giving them real design tasks and using pilot tests.

In response to these identified limitations, the purpose of this study was to present a lifecycle-based design guideline tool to develop resource-efficient products in the early design stages. The tool is intended to guide the designer to relevant design recommendations depending on product characteristics. The tool is primarily aimed for designers; however, as pointed out in the tool, it can be used by other personnel to initiate training in resource efficiency and life cycle thinking (see Supplementary Materials, REDIG tool). The tool is also intended to provide information about environmental trade-offs, to cover design measures over the whole product lifecycle that lead to resource efficiency, and to be applicable for all product types. The proposed design guideline tool was evaluated with a design case in terms of usability and usefulness.

Usability was defined as (1) whether the tool is easy to use and understand and (2) the likelihood of implementation in practice. Usefulness was understood as (1) whether the tool is informative and (2) whether it leads to the improved resource efficiency of a design concept. The term "product" is used here to denote products, services, and combinations thereof that conform to the standard for the life cycle assessment (LCA) of the International Organization for Standardization [28]. Resource efficiency (RE) is defined as fulfilling the same function (of a product) with less resource use and environmental impact. In line with Kjaer, et al. [29], we considered the ultimate objective of the CE to be resource efficiency, which is we focused on RE. Consequently, measures over the whole product lifecycle leading to RE were considered. The design of business models was outside the scope of this study; however, they are briefly addressed in the tool. The term "lifecycle" can be used with different meanings in different fields. We use the term here in accordance with LCA, meaning that a product's lifecycle starts with the extraction of raw materials, followed by material production and manufacturing, use, and subsequent post-use treatment. We chose the early stages of design because the potential to influence the design and the environmental impacts of a product are the highest at this stage according to Bhamra, et al. [30]. 


\section{Methods}

An overview of the research process for developing the tool and the study is illustrated in Figure 1. The design guidelines presented in the figure draw on two papers: Böckin, et al. [15] and Tillman, et al. [31]. Böckin, et al. [15] completed a literature review to identify which product characteristics are decisive for the outcome of different RE measures. This was achieved by synthesizing learnings from 59 lifecycle-based assessment studies of different products and RE measures. In Tillman, et al. [31], the learnings from Böckin were reformulated into guidelines in which identified product characteristics provide a guide to suitable measures.

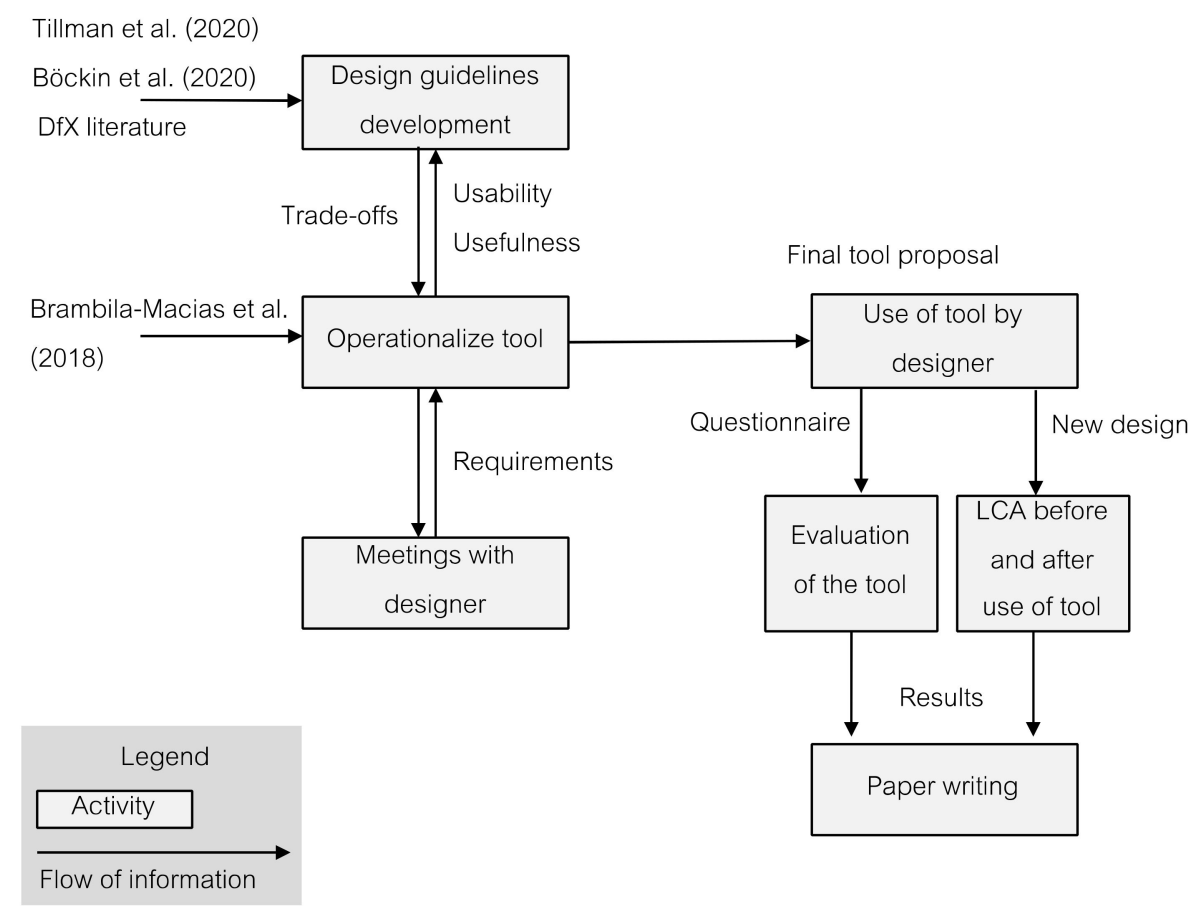

Figure 1. Research process for the study.

To focus the guidelines on design aspects, the recommended measures from Tillman, et al. [31] were complemented with existing design guidelines mainly found in design for $\mathrm{X}$ literature. This was conducted to add concrete examples of how the measures could be accomplished through different design considerations to provide more detailed information for the guidelines.

To operationalize the guidelines into a useful tool, several meetings were held at a case company in the transport sector to support a designer with making a component more resource efficient during 2018-2019. The company was selected given its interest in resource efficiency and their support for this research. The tool is intended to be useful in all manufacturing sectors and not only the transport sector. For studies providing more details relevant to the transport sector and RE, please see Schöggl, et al. [32] and Poulikidou, et al. [33]. The first meeting involved a discussion about the type of design support of interest to the designer, for instance, design guidelines or specific assessment tools similar to LCA. At the second meeting, a requirement list developed in Brambila-Macias, et al. [34] was used to collect the specific user requirements of the designer. These were collected to address the usefulness and usability of the tool. The tool was thereafter developed based on the design guidelines and the requirements from the designer using an iterative process. An initial presentation and test of the developed tool was conducted in February 2019 with the designer. Insights from the pilot test pertaining to the layout and usability of the tool were then implemented. A final test of the tool was conducted by one designer in September 2019 to gather feedback on usability, usefulness, and potential improvements. 
The usability ( 1 and 2) and usefulness (1) of the tool were evaluated by the designer using a questionnaire. The questionnaire consisted of two sections: before use and after use of the tool (see Appendix B). The before-use section mainly evaluated the familiarity of the designer with working with environmental issues, their general design experience, and experience in using methods and tools. The after-use section aimed to provide information about the usefulness and usability of the tool. Usefulness was evaluated with questions on the familiarity of the designer with the design recommendations and trade-offs provided in the tool, and whether the designer was satisfied with the generated design concept. Usability was evaluated through questions about whether the tool was easy to understand and use, and the likelihood of implementing it in practice. In parallel, usefulness (2) was evaluated by means of an LCA study that compared the environmental performance of the new design concept to an existing one. If a concept with less resource use and environmental impact was developed, the concept was deemed more resource efficient (Figure 1).

\section{Design Guideline Tool}

\subsection{Tool Overview}

From meetings with the designer, we determined that support in the form of guidelines similar to the 10 golden principles [35] was of interest (another similar design guideline approach is the eco-design strategy wheel by Brezet and van Hemel [36]). This would be support that includes measures pertaining to the product's material content, optimization of product lifetime, and restorative measures, among others. Other factors to be supported by the guidelines were the suitability of the measures and information on possible trade-offs.

The design guideline tool, Resource Efficient DesIgn Guidelines (REDIG, which means orderly, clear, lucid in Swedish), consists of four parts (Supplementary Materials, REDIG tool). The first part is an exercise where the designer qualitatively draws the material flows of the current product's lifecycle (Figure A1, Appendix A). This is achieved by mapping the main processes of the product lifecycle from the extraction of resources, across production and use, to post-use treatment. The purpose is to enable lifecycle thinking and to visualize the consequences of changes in the product system.

The second part consists of two guideline question trees (Figures 2 and 3), which help the designer to identify relevant product characteristics and direct them to appropriate design guidelines. These product characteristics are based on the kind of environment and resource-related hotspots of the product, and thus point to what is important to consider during design. The third part consists of the design guidelines, divided into three sub-groups. Design recommendations are given in the first group depending on product characteristics. These recommendations are all related to the use phase, including reuse (Table A1 for durable products, Table A2 for consumable products; Appendix A). The second group is relevant for all types of products. It provides design recommendations with implications for production and consequently material selection (Table A3). The third group consists of design guidelines with implications for the post-use phase. RE measures for post-use were determined less by product characteristics and more by the material content of the product (Table A4). The fourth part consists of additional information on each design consideration to exemplify how improvements can be achieved (Table A5).

A durable product, in this context, was defined as a product that can be used for a long time and whose function does not deteriorate rapidly during use. Examples include cars, furniture, tools, etc. In contrast, consumable products are short-lived products. They can be divided into three types: dissipative products are consumed immediately or gradually during use (e.g., food, energy, cleaning agents); disposable products are typically used once and thereafter disposed (e.g., packaging, single-use products, and hygiene products); short-lived components in durable products have a relatively short lifespan in relation to the whole product and must be replaced when product function has deteriorated (e.g., filters in vehicles or an AA battery in a remote control). 
The design guidelines presented in the subsequent sections are structured as follows: first, the recommended design measure (activities aimed at improving RE) is explained with concrete examples built on findings in Tillman, et al. [31]. Second, relevant design considerations (how the design measure can be practically achieved) are described in relation to the measure. These considerations are both preconditions and enablers of the measure. Third, potential trade-offs are presented in relation to the measure and/or in relation to the design considerations if such have been identified. Note that, regardless of design measure, the safety of the user and the functioning of the product should always be prioritized.

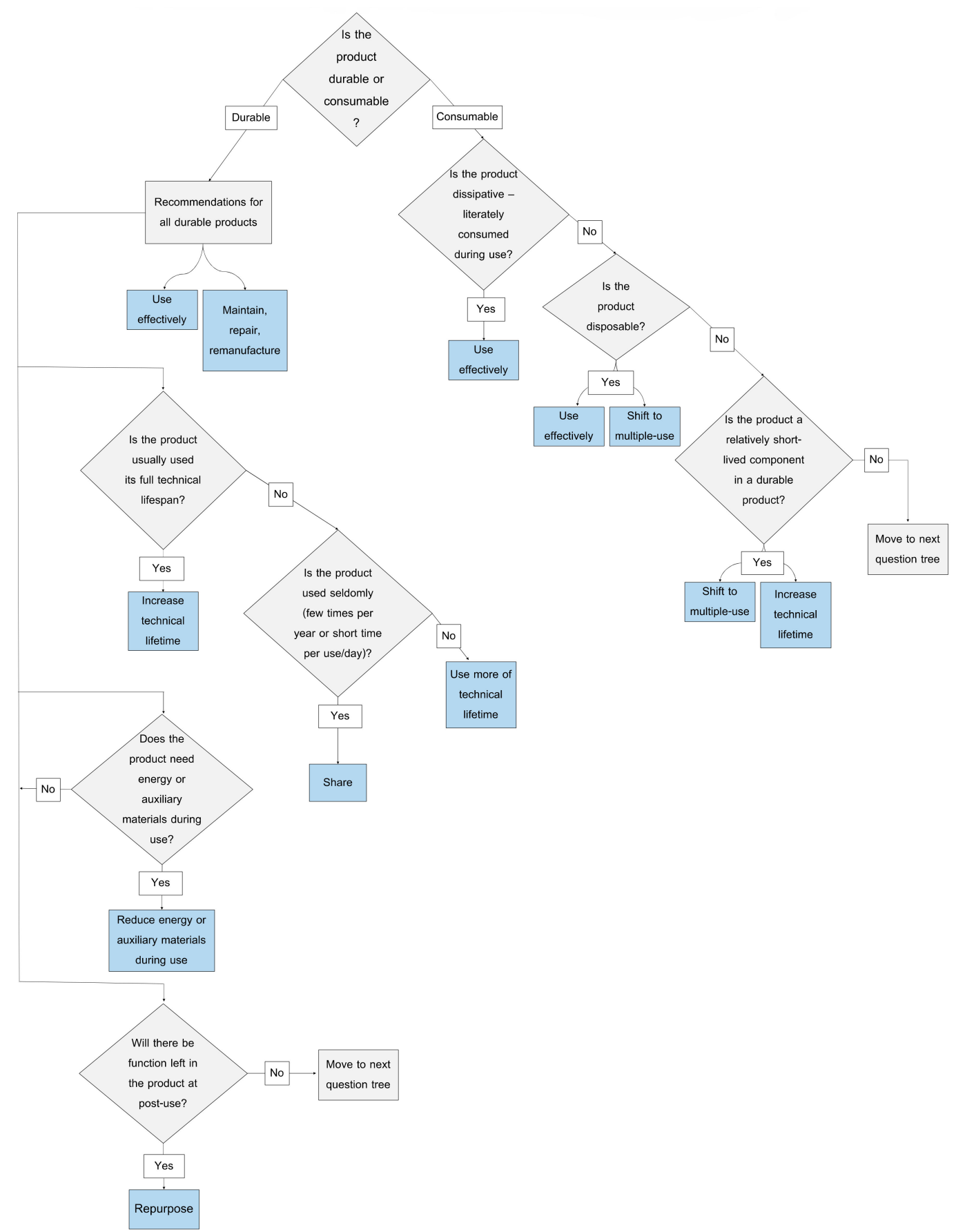

Figure 2. Guideline question tree for product specific guidelines. Note that several product characteristics can be relevant for a durable product; hence, the entire question tree must be viewed. 


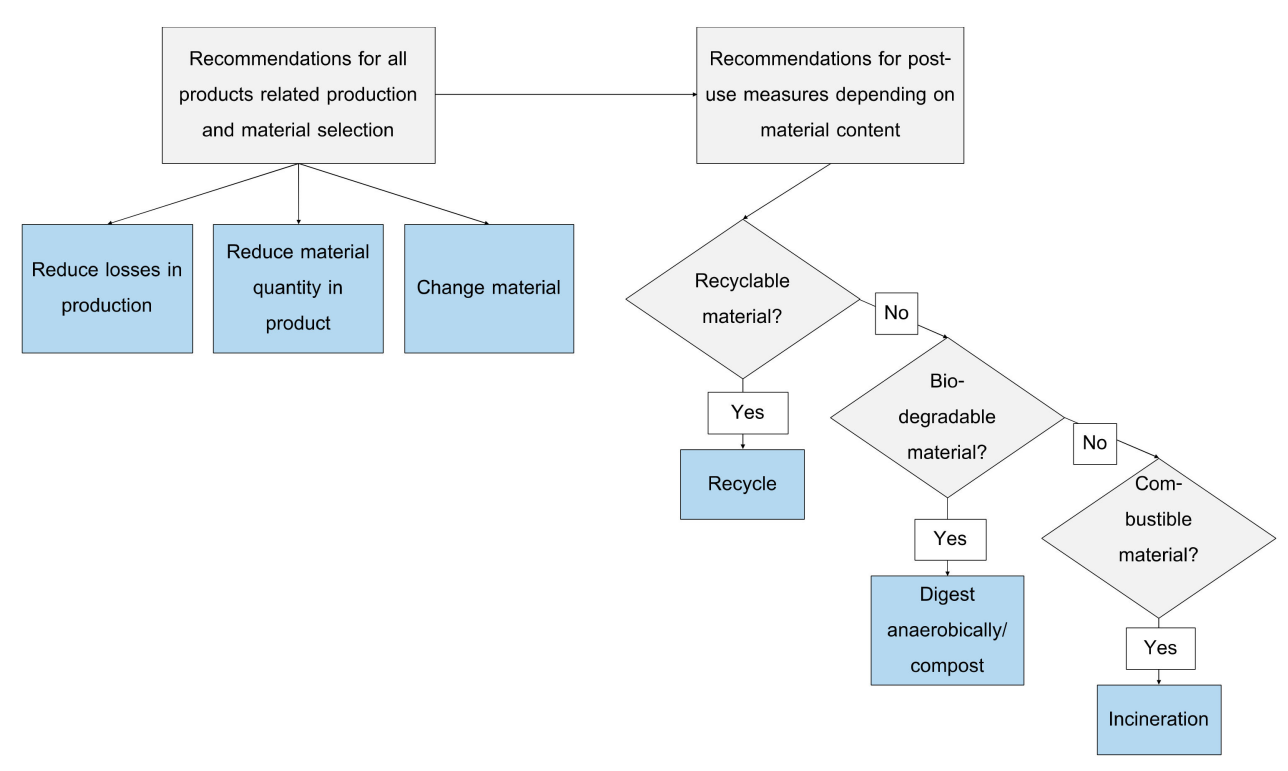

Figure 3. Guideline question tree for all products.

\subsection{Guidelines for Durable Products}

Many design measures are possible for durable products; some depend on product characteristics, whereas others are general guidelines (Table A1).

\subsubsection{General Guidelines for Durable Products}

Two groups of measures are possible for all durable products: use the product more effectively or maintain, repair, and remanufacture the product.

The first recommendation for durable products is to use them more effectively, which means to provide a product with the appropriate function and to use it for its intended purpose.

Design considerations: user-centered design can aid with understanding how a user will use the product [37], which will enable more effective use. Functionality matching, which entails designing products with only the needed function of the user and not over-specifying, is one example of this design [37]. No trade-off is identified for this design measure.

The second recommendation for all durable products is to maintain (i.e., inspect, maintain, and protect before failure), repair (i.e., repair after wear, malfunction, or failure), or remanufacture (i.e., restore product to functional state as good as new or better).

Design considerations: For restorative measures to be applied to a product, the product must be designed and planned accordingly, for example, identifying which components require replacement during use, and planning how the replacement should occur. Design for disassembly is important in this context [38] and could involve the use of standardized joints, the use of fasteners instead of adhesives, minimizing the use of connectors, and implementing a modular design $[38,39]$. Other considerations involve designing the reduction in the need for maintenance by identifying possible failures, initiating preventive maintenance, and ensuring that maintenance is easy [14,40]. Error-proof design [41] means reducing the potential for mistakes during use, thus reducing wear and tear, and ultimately repair and maintenance. This can be achieved with lock-ins, lockouts, and interlocks to prevent errors from occurring and by making it difficult to proceed until an error has been corrected. Another example is warnings, such as lights, information displays, and reminders that inform users of errors [41].

Several potential environmental trade-offs are associated with the restorative measures. First, the measures could increase the need for transportation and associated environmental impacts. Second, if the product is modular, there is a risk of greater material usage. Third, if sensors are used to monitor the product, there could be a trade-off between the benefits of their use and the impacts of producing 
sensors. Lastly, for an active product with fast technology development toward energy efficiency in the use phase, it would perhaps be preferable to replace this product with a new and more efficient product instead of making the product last longer.

\subsubsection{Products That Are Seldom Replaced}

Increasing the lifespan of a product is recommended for products that are commonly used for their full technical lifespan without changing user, which entails designing components or products to last longer.

Design considerations: designing for durability often means that more materials or more robust materials are used. It can also entail designing the same service life for different components, thus simplifying product design and eliminating weak links of the product structure to ensure reliability [14]. A product must also be used throughout its lifespan; hence, emotional durability is important, which can be accomplished through design for attachment [16]. Examples include design that enables product personalization, products that age with dignity, or that allow the user to capture memories.

Trade-offs connected to design for durability involving the use of more material or more environmentally impacting materials may outweigh the benefits of longer product life.

\subsubsection{Products Typically Discarded before Wearing Out}

Design that ensures the product is used for its full technical lifespan is recommended for products typically discarded before they wear out. This could either entail ensuring that the first user continues to use the product throughout its lifespan, or that it is reused by a new, second-hand user.

Design considerations: the design of such products should aim to avoid obsolescence. Timeless design is one option of reducing the user's urge to prematurely discard the product by avoiding fashion trends. Since consumers exert considerable influence on product lifespans and may attach emotions to products, design for attachment is another strategy [16]. A third consideration is design for upgradability, such as modular design or disassembling the product to enable upgrading its function or performance [14]. Similarly, design for adaptability, which provides the potential of changing the aesthetics or functions of the product during use, is a fourth design strategy [14].

One potential trade-off connected to reuse through second-hand sales is the risk of inducing transportation that may outweigh the benefits of reuse. Regardless, the purchase of new products also implies transportation.

\subsubsection{Products Infrequently Used and Typically Discarded before Being Worn Out}

Sharing is recommended for products that are typically discarded before they are worn out and are infrequently used. Sharing means the products are used regularly by several users, such as library books, rented tools, or communal washing machines.

Design considerations: problems that may arise with shared products are that they are often used carelessly by several users, which leads to excessive wear and the premature disposal of the products. Robust design, design for maintenance, and user-centric design are important to overcome these obstacles. Robust design entails the materials and the construction of the product being durable. Modular design and design for easy disassembly are suggested to facilitate maintenance. A uniform and simple design can help many users to understand how to use the product properly. Similarly, error-proof design may be important [41]. The users should also want to use shared goods. For this reason, understanding user requirements for sharing is relevant to the achievement of sharing [42]. For instance, a product can be designed to be easy to clean if cleaning is required by the users between each use cycle [42].

In terms of trade-offs, there is a risk that the impact from transportation outweighs the benefits of sharing, depending on the mode of transport to access the shared stock [43]. 


\subsubsection{Active Products}

For active products, reducing energy or auxiliary materials during use is a recommended measure. Examples include the design of water-efficient household appliances or energy-efficient machines, vehicles, buildings, and electronics.

Design considerations: design for energy (and water) efficiency can be enabled through sensors that ensure the product is only in use when needed. Sensors can also be used for eco-feedback, which means monitoring the energy and water usage, and informing the user about the consumption in an effort to change user behavior [37]. Designing electric and electronic products for efficiency usually entails technology development for reduced electricity usage. Design for light weight [44] is especially relevant for vehicles and machines for which fuel consumption increases with increased weight. This can be accomplished through the use of lighter materials or a hollow product structure. Finally, design for upgradability is important for active products with fast energy efficiency development. The objective is to reduce the risk of the product becoming technically obsolete and to allow for improved components to be replaced instead of replacing the entire product.

There are several trade-offs of which to be aware when designing for efficient active products. As mentioned, a trade-off exists between replacing and extending the use of active products with rapid efficiency improvements. Another concern is lightweight design, which could lead to reduced durability (if less durable materials are used) and the increased replacement of components. Lightweight design can also involve more environmentally impactful materials being used or materials that are difficult to recycle, such as composites [45]. Lastly, the production of sensors could outweigh the benefits of use-phase savings.

\subsubsection{Function Partly Remains Post-Use}

Design for repurposing is recommended for a product whose function partly remains when it no longer can be used for its original purpose. This means reusing a product, or its parts, in a different function than the original, for example, the reuse of automotive batteries for stationary energy storage.

Design considerations: design for cascades is one option for considering the use of the remaining function of a discarded product. This entails planning and preparing the product and its components for multiple life uses with different functions in each life [14]. For instance, this could entail optimizing materials to ensure that correct or sufficient function is in place for each life. Another option is design for disassembly to ensure that parts with remaining function can be accessed. Communicating the specifications of products and components can also facilitate repurposing. No trade-offs have been identified for repurposing.

\subsection{Guidelines for Consumable Products}

Design recommendations for consumable products depend on whether a durable product is dissipative, disposable, or has short-lived components (Table A2).

\subsubsection{Dissipative Products}

Dissipative products, such as food, electricity, and cleaning agents, are recommended to be designed for effective use. This can be achieved by delivering only the necessary function to ensure that only the needs of the user and product function are fully matched. This notion includes enabling the product to be used for its intended purpose and avoiding losses during use.

Design considerations: effective use can be achieved via user-centered design [37,46]. Design for the smart distribution of products is another approach to achieve effective use. This includes designing suitable packaging sizes, smart dispensing that delivers only the needed quantity, and packaging shape that enables the packaging to be fully emptied. The first two examples involve design for eliminating mismatches between delivered functionalities of a product and the desired functionalities of the user [37]. The second example is also about portion control, which involves design that ensures 
that users only consume a sufficient amount of a product. The third example simply ensures that packaging is designed so that the product can be efficiently fully used. Effective use can also entail increasing the functionality of a product to improve system efficiency. Examples include detergents that function at lower washing temperatures and fuel additives that increase engine efficiency.

Design for sustainable behavior [47] can also aid with effective use. This entails making it easier for people to adopt and to want to adopt a desired behavior, and making it harder to perform undesired behavior [47]. An example of how user behavior can be influenced is through eco-feedback or forced functionality [48]. This could include sensors and control units that inform about proper use or make it difficult to use the product incorrectly. However, a potential trade-off exists between the benefits of sensors and their production.

\subsubsection{Disposable Products and Components}

Two design measures are recommended for disposable products such as tissues, packaging, and hygiene products, and for disposable/short-lived components in durable products, e.g., ink cartridges, single-use batteries, and disposable machine components. The products should be designed for effective use, with the potential to redesign a disposable product to a multiple-use product.

Effective use for these product types means delivering only the needed function, use for an intended purpose, and avoiding losses during use. An example of avoiding losses is designing hand-towel dispensers that only provide one towel at a time.

Design considerations: user-centered design can aid the designer in understanding how the user will use the product and how resource waste can be reduced [37]. For instance, foldable shapes could enable more efficient transport to recycling for packaging material. Information about correct usage through sensors and design that provides users with recommendations can also enable effective use. Examples include indicators for remaining function, such as diapers with color indicators to show the amount of absorbed liquid. However, as mentioned, trade-offs could exist between the production of sensors and resource savings.

The second recommended measure is shifting to a multiple-use product. This entails designing a washable, rechargeable, or refillable product.

Design considerations: to accomplish this shift, a complete redesign of the product is usually required. This means that a more durable product that can handle maintenance must be designed. If the whole product cannot be designed for reuse, perhaps parts of the product can be made reusable. Transitioning from a single-use to a multiple-use product also requires the user to want to reuse it. The tendency to reuse a product can be influenced by hygiene, i.e., the product is clean enough to reuse; consequently, the design should promote hygiene. Design for attachment could be important to ensure that the product will be used for a long time [16].

Potential trade-offs connected to shifting to a multiple-use product are linked to its production and maintenance; producing a multiple-use product usually requires more resources and produces more of an environmental impact per item than producing a disposable option. The multiple-use product must therefore be sufficiently used to limit these impacts. The maintenance of the multiple-use products can also lead to increased environmental impact and outweigh the benefits of reuse. Therefore, it is also important to design an energy-efficient maintenance system.

\subsection{Guidelines for All Products}

This section presents design recommendations that are relevant to all products in terms of material selection and production (Table A3).

First, reducing losses in production can improve resource efficiency for any product system.

Design considerations: Reducing losses is about process design and the design of manufacturing systems [49]. Measures include aspects such as reduced scrap rates and other resource losses in production, increased energy efficiency in production, or the valorization of by-product flows internally (process integration) or externally (industrial symbiosis) [14,50]. Choices can be made during product 
design that reduce material losses in production, e.g., avoiding complex product structure and details can reduce losses when cutting materials. The only identified potential trade-off is when it requires energy (or other resources) to reduce material losses, or to recover scrap and by-product streams.

Second, a reduction in material quantity in products where material substitution is impossible is recommended.

Design considerations: a reduction in material or the more efficient use of a given material for a given function (also called dematerialization [51]) can be accomplished by designing thinner layers of a specific material or non-massive designs, such as truss and shell structures. Another approach to reduce material quantity is by removing water from products, e.g., designing a concentrate and letting the user add the required water. This results in less packaging with less material, which reduces impacts from transportation. This is particularly relevant for food and detergents. Reducing unnecessary materials in packaging or designing out the need for packaging are two additional examples of reducing the total material quantity of a product system [14].

There are two potential trade-offs when reducing materials in products. The first concerns that there is a risk for losing function such as durability. The second concerns the benefit of removing water and the impact of removing water for the concentrate design option.

Third, materials in products can be substituted with more environmentally benign materials.

Design considerations: material substitution suggestions include replacing fossil-based material with bio-based material, increasing the share of recycled material, substituting hazardous constituents, and substituting scarce materials. Changing materials to those with well-developed recycling processes is also recommended. For material substitution to be successful, the material's functional properties must be matched. For products that risk uncontrolled dispersion (e.g., littering and the degradation of surfaces), biodegradable and non-hazardous materials can be used. However, whether a material is degradable in natural or industrial conditions must be verified. Biodegradable, according some standards, means biodegradable under industrial conditions $\left(70^{\circ} \mathrm{C}\right)$ [52]. Lastly, where and how biomaterials are cultivated and harvested are vital to avoiding the implications of land use-related issues, such as biodiversity degradation.

There is always a risk of trade-offs between the types of environmental impacts when substituting materials. For example, there is a trade-off between climate impact and impact from land use when fossil-based materials are substituted with bio-based ones.

\subsection{Guidelines for Post-Use Measures}

The last aspect to consider, regardless of product type, is how the product is to be treated post-use (Table A4). Which treatment type is possible depends on the materials composing the product. The complexity and the level of integration of materials are important for efficient post-use treatment. Thus, the possibility of separating components and materials is important for all products.

Recycling entails returning materials back to use. Recycling is particularly relevant for products producing significant impacts from material production. Effective recycling should aim for as little quality degradation as possible, and several design aspects must be considered to achieve this goal.

Design considerations: design for recycling $[14,53]$ includes a multitude of approaches: use as few or as uniform materials as possible, label materials, and locate components of similar materials together. Fusing materials, such as composite materials and alloys, should be avoided, as these materials can be difficult to recycle. Easily liberated components and connectors should be used so materials can be easily separated in recycling grinders. Lastly, materials that can be easily recovered to their original performance after recycling should be chosen. There are some obstacles to recycling, such as the variety of colors of plastic and glass. Recycling also risks keeping hazardous substances in circulation; hence, hazardous substances should be avoided. There could be trade-offs between recycling and other measures. For example, a recyclable product (a plastic single-use cup) can be difficult to use long-term, whereas a durable product can be difficult to recycle (a ceramic mug). 
Biodegradable products can be digested anaerobically or composted. Anaerobic digestion is preferable since it yields biogas and a digestate containing nitrogen, phosphorus, potassium, and organic matter that can be used as fertilizer. In contrast, compost generates no biogas and has a low nitrogen content but can be used as a soil enhancer [54,55].

Design considerations: since only biodegradable material can be digested anaerobically or composted, such products should preferably be designed to contain solely biodegradable materials.

Combustible products can be incinerated with recovery, yielding heat, and/or electricity.

Design considerations: to reduce slag, completely combustible products should be used. Otherwise, design for disassembly to separate recyclable parts and combustible parts. Hazardous metals should be avoided, as well as halogens, since they generate hazardous flue gases and slag.

\section{Tool Evaluation}

The evaluation of the tool started with evaluating the designer's own design and sustainability experience, which is presented in Appendix B.

\subsection{During Use}

The designer used the tool for an air filter used in a truck. The designer was first instructed on the tool's layout and how the tool worked. Thereafter, the designer used the tool to identify suitable recommendations for the air filter.

The lifecycle of the air filter is shown in Figure 4. The function of an air filter is to protect an engine and to clean the air intake to the diesel engine of a truck. There are three main components of an air filter: filter paper material, which absorbs particles from the air (mainly dust from the road) during use, a basket of polypropylene (PP), which the filter material molds into to keep the filter in place during use, and a seal of polyurethane (PUR), which seals the whole filter component together as a lid and bottom. The lifetime of the air filter is approximately $40 \mathrm{~h}$ per week for two years, after which it is replaced (as part of truck maintenance). The used air filter is incinerated.

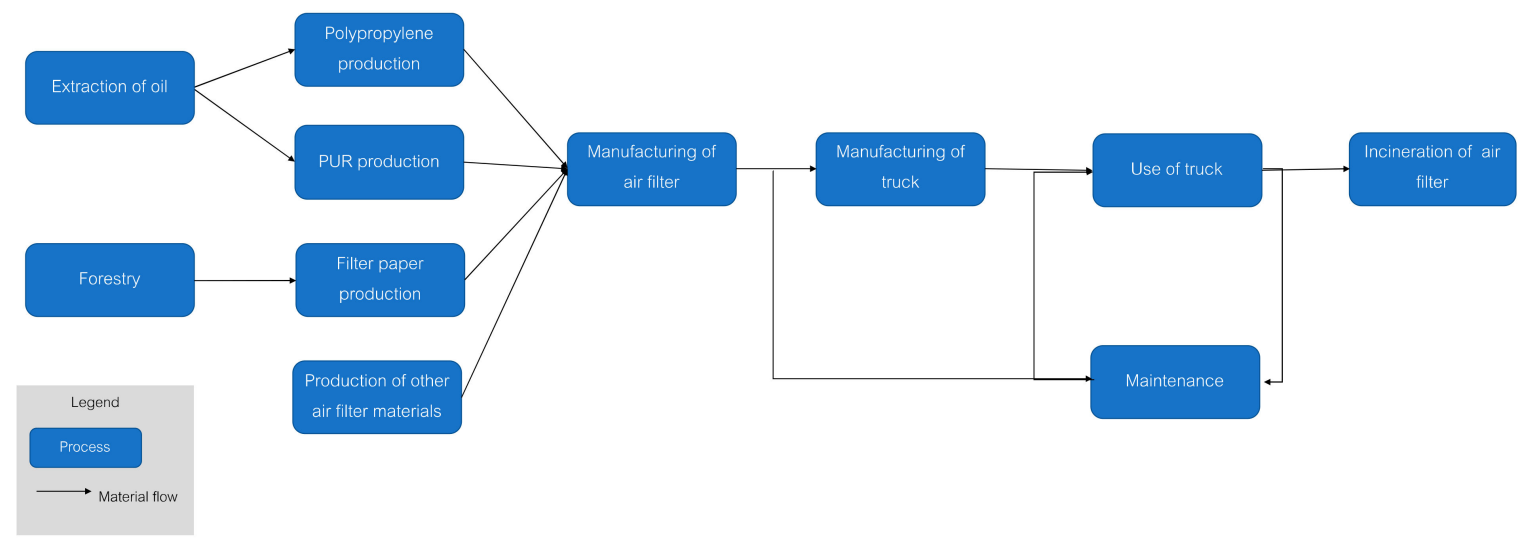

Figure 4. Lifecycle of the current air filter from cradle to grave.

The designer classified the air filter as a short-lived component in a durable product since it has a relatively short lifespan in relation to the truck and must be replaced several times during the truck's lifetime. Two possible design measures were suggested: turn it into multiple-use product and prolong the lifespan of the product. The first suggestion was not found suitable for practical and legal reasons (an air filter must be incinerated or landfilled post-use, depending on country). The latter option was found possible. Of the recommendations for all products, changing to bio-based instead of fossil-based materials was considered suitable. No changes were deemed possible for post-use.

The following design considerations were considered possible (Figure 5): first, a change of materials from fossil- to bio-based by changing the PP and PUR materials to a polylactide-based biopolymer (PLA) made from corn; second, increasing the technical lifespan of the air filter by increasing 
the material content of the filter by $10 \%$. This measure would increase the lifetime of the air filter by $20 \%$, according to the designer.

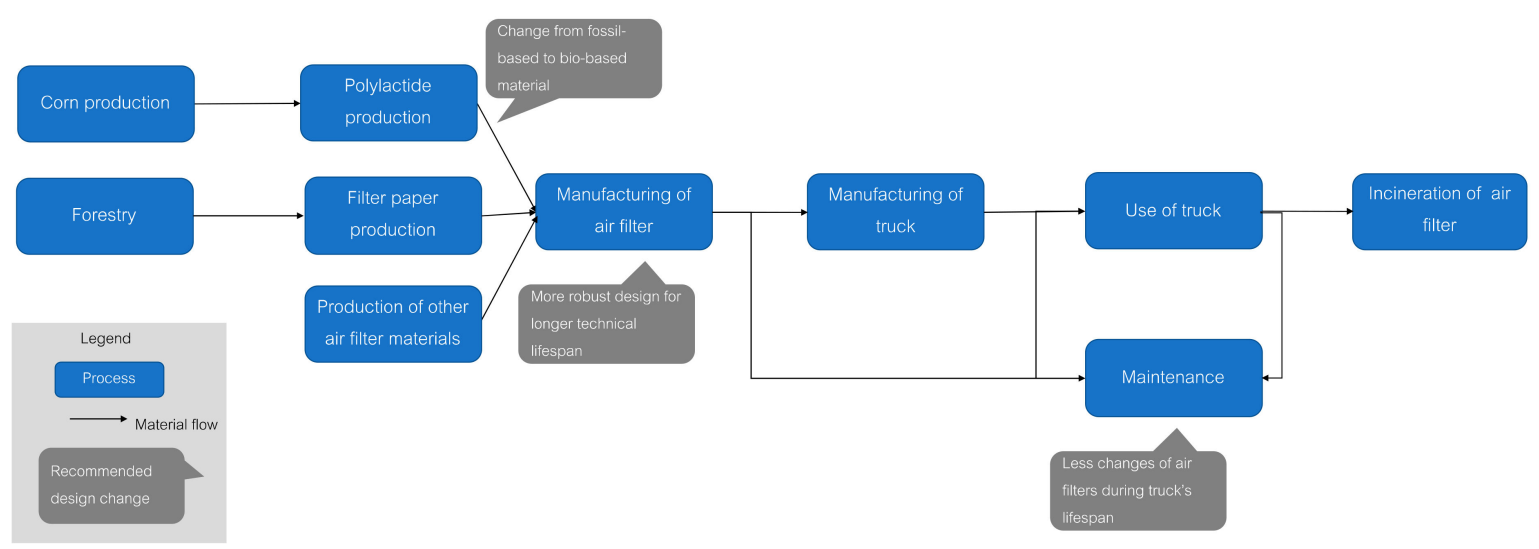

Figure 5. Lifecycle of redesigned air filter from cradle to grave.

\subsection{After-Use}

The second part of the questionnaire (see Appendix B) was used to evaluate the usability ((1) and (2)) and usefulness (1) of the tool. Regarding usability (1), the designer categorized the use of the tool as easy and very understandable. It was also possible to determine the designer's likelihood of incorporating the tool into design practice (usability (2)), which was reported to be very likely. The evaluation of usefulness (1) showed that the recommendations were informative. Further feedback from the designer is provided in Appendix B. The usefulness (2) was evaluated by conducting an LCA of the current air filter and an LCA of the redesigned concept.

\subsubsection{LCA}

Information about the current air filter's lifecycle was collected from the designer. Both air filters and their constituent materials were assumed to be produced in Europe or the U.S., in line with current production. Truck assembly and its subsequent use, changes of air filters, and post-use treatment were assumed to take place in Sweden. No site-specific data were collected. Instead, data were sourced from the Ecoinvent 3.5 LCI database [56], and the study was conducted using OpenLCA software [57]. The lifecycles of the two air filter options were modeled from cradle to grave, excluding maintenance activities, impacts from the use phase, and transport to post-use treatment, since these processes were assumed to be the same for the two filters (see Table 1 for details on the air filters). The functional unit was set to "filtering air to a diesel engine during the technical lifespan of the current air filter" to capture the difference in the lifespan of the two air filters.

Table 1. Details of the current and redesigned air filter.

\begin{tabular}{ccc}
\hline Materials and Mass (kg) & Current Air Filter & Redesigned Air Filter \\
\hline Polyurethane (PUR) & 1.65 & \\
\hline Polypropylene (PP) & 0.75 & 1 \\
\hline Paper filter & 0.9 & 2.64 \\
\hline Polylactide (PLA) & & 3 \\
\hline Absorbed particles during use & 2.5 & 6.63 \\
\hline Incinerated mass & 5.8 &
\end{tabular}


Impact Assessment Result

The 2008 version of the ReCiPe midpoint with a hierarchist perspective was used for impact assessment [58] (the latest ReCiPe version in Ecoinvent method package 3.5) to include a multitude of impact categories. The result from the impact assessment showed a decrease in most of the environmental impact categories (Figure 6). It was also clear that combining the measures of changing to bio-based material and increasing the lifetime of the filter by increasing the amount of material led to the greatest improvement. Among the impact categories, ozone depletion, followed by fossil depletion and climate change, lead to the most significant improvements. This was mainly due to the shift to bio-based plastic.

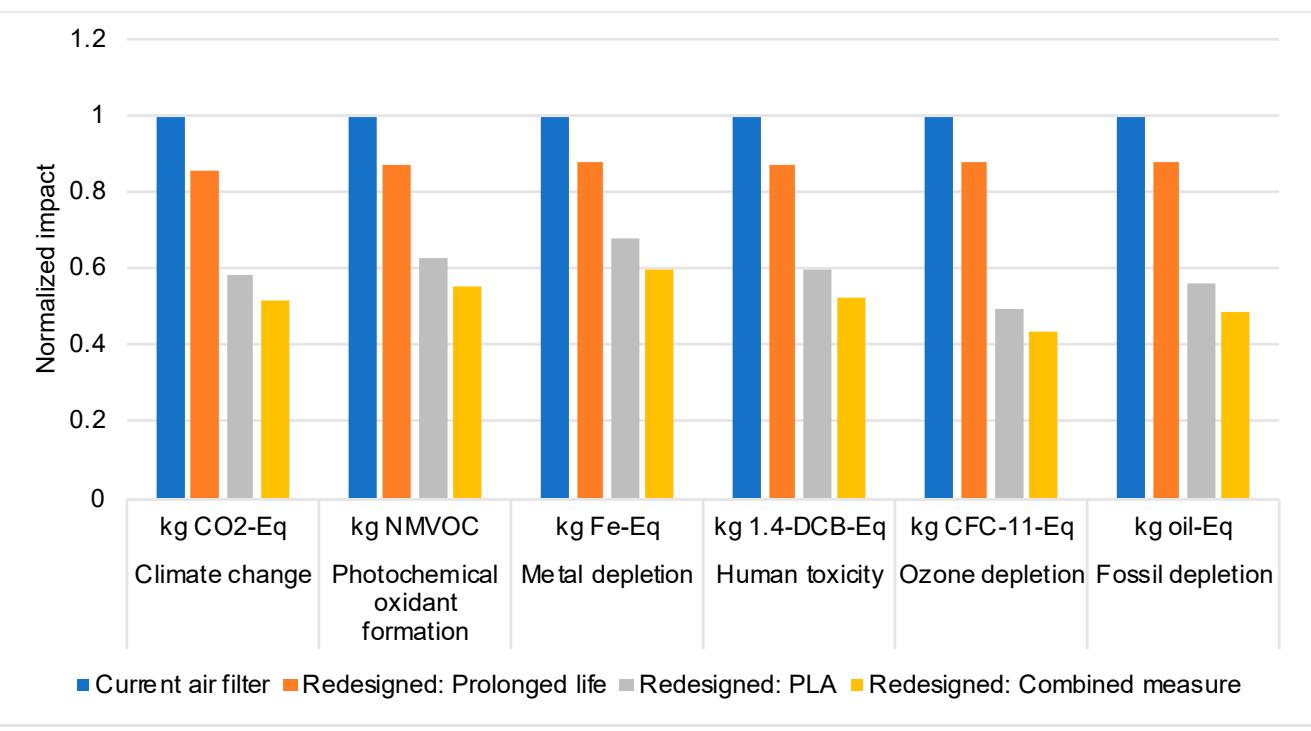

Figure 6. Impact assessment result for the current air filter compared to the redesigned air filter with combinations of the impact categories that lead to a lower impact.

However, the impact increased substantially for the categories of water depletion and terrestrial toxicity, as shown in Figure 7. Agricultural activities related to corn production were the reasons for the increased impact of these categories.

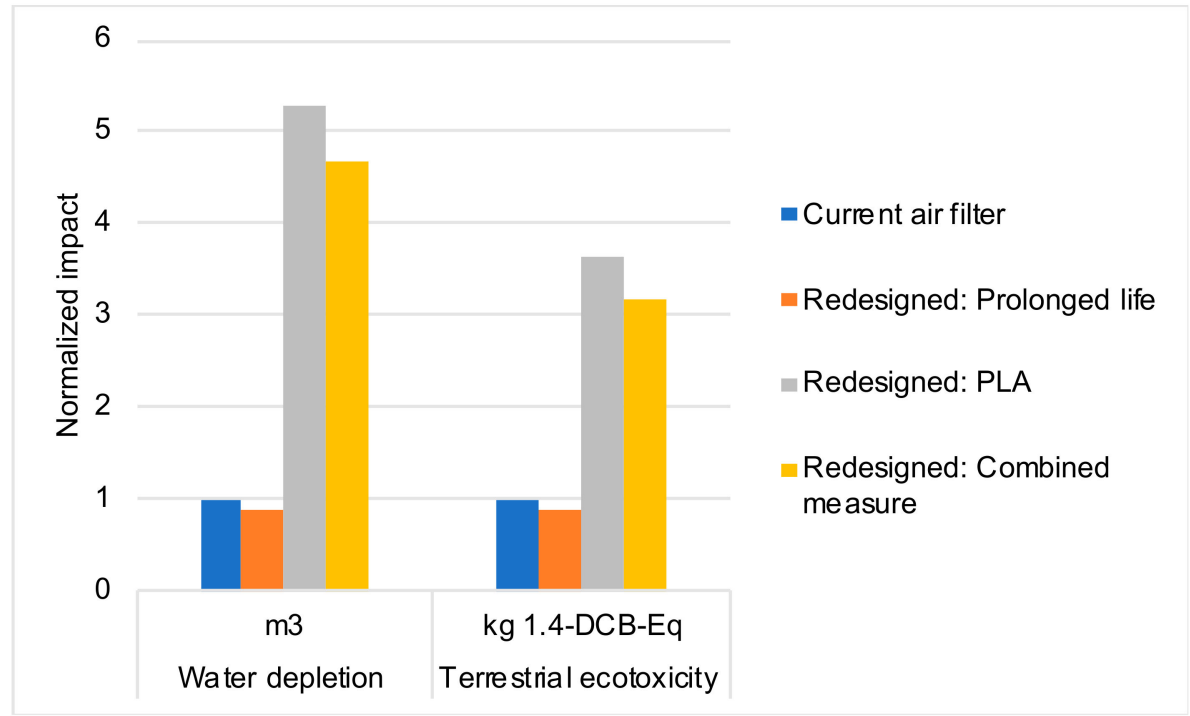

Figure 7. Impact assessment result for the current air filter compared to the redesigned air filter with combinations of impact categories that lead to greater impact. 


\section{Discussion}

A design tool that guides the designer to recommended guidelines depending on product characteristics was presented. The tool provides information about environmental trade-offs and covers design measures over the whole product lifecycle, leading to RE. The tool is intended to be applicable to all types of products. The tool was evaluated in terms of usefulness and usability in a design case to evaluate whether these goals were met.

A comparison of the LCA results between the redesigned and the current air filters showed that the redesigned concept led to overall lower environmental impact and resource use. As expected, the design resulted in increased environmental impact associated with agricultural activities from corn production, since the product concept substituted fossil- with bio-based materials [59]. However, the impacts of climate change and fossil resource depletion improved by $50 \%$. The findings also showed that larger RE gains are achieved by combining two nonconflicting design measures. This indicates that combining measures could be generally important to consider when designing new products to achieve greater RE improvements.

Thus, when evaluating usefulness (2), the tool helped develop a more durable concept with bio-based plastic instead of fossil-based plastic. The evaluation of usefulness (1) showed that the tool was informative to the designer. Regarding usability ((1) and (2)), the designer considered the tool easy to use and the designer stated they would likely incorporate the tool into their practice. Involving the designer in the development of the tool and reflecting on how the tool could address their needs and those of the company were determinants in increasing its usability.

The evaluation was conducted in one design case by one designer and can only provide a preliminary indication. Multiple tests with different products in different companies are needed to more comprehensively evaluate the tool's usability and usefulness. This is suggested for future research. The tool does not guarantee that a more resource efficient solution will be developed. LCA is necessary to verify whether a concept is resource efficient. Nevertheless, the tool provides fact-based guidelines, since they were derived from LCA studies and recommendations therein.

\subsection{Comparison with Other Tools and Methods}

To assess the originality of, and the motivation for, developing the design guideline tool, this section compares the REDIG tool with other tools and methods with similar aims. Several similarities and differences were identified in a comparison of the developed tool with the 10 golden principles (GP) method [35]. If the GP method had been tested in the present study, we would have expected a similar design concept to be developed. The reason for this is that both methods include a lifecycle perspective in their recommendations, recommending increasing the lifetime of products, and shifting from fossilto bio-based materials. Both methods include recommendations concerning hazardous substances, energy consumption in active products, recycling, product lifetime, promoting repair and upgrading, and providing information to ensure proper usage. Another similarity is that both methods provide information about trade-offs connected to the guidelines. Lastly, neither method ranks the guidelines.

However, several differences were found in the two guidelines. First, the developed tool provides guidelines based on product characteristics, whereas the GP method provides general guidelines that require customization to be useful in a specific product development process [60]. Second, the guidelines differ in their coverage of measures. The GP method includes measures concerning human resource, economy, and business contexts, which are not included in the developed tool. Instead, our tool contains guidelines for more RE measures such as reuse, remanufacturing, sharing, multiple-use products, how to avoid obsolescence, and design for sustainable user behavior. Consequently, the REDIG tool covers more aspects of relevance in the context of designing for resource efficiency.

Comparing the developed tool with tools with similar purposes, several similarities and differences were found. Product lifecycle management (PLM), which is rooted in computer-aided design (CAD) and product data management (PDM) systems, "is a business solution which aims to streamline the flow of information about the product and related process throughout the product's lifecycle such 
that right information in right context at the right time can be made available" [61] (p. 1). PLM can be used in eco-design, in which product and component data can be gathered from the PLM software into simplified LCA software [62]. Another similar method was proposed by Gmelin and Seuring [63], which uses PLM together with LCA, life cycle costing (LCC), and social LCA (SLCA) for sustainable product development. However, the latter is not yet fully developed; rather, it is a theoretical framework [64]. The PLM-based tools and the REDIG tool provide a life cycle perspective; however, whether the PLM tools can provide design suggestions relevant to the redesigned product is unclear.

Another computer-based method is case-based reasoning (CBR), which is an artificial intelligence (AI) methodology that is used specifically in problem solving [65-67]. By using previous similar cases from a database, the CBR method simulates human problem-solving behaviors to solve or interpret a current problem [67]. One such CBR tool intended for eco-design purposes was developed by Germani, et al. [68]. Similar to our tool, it entails characterizing the product intended to be redesigned to identify relevant eco-design guidelines. However, in contrast to our tool, the starting point of their approach is an analysis of the environmental impact of the product (via a full or simplified LCA) to identify the hotspots [68]. The guideline question tree provided in our tool is intended to aid the designer in identifying the relevant product characteristics, which builds on learnings from LCAs about product hotspots, and, in that way, steers the designer to suitable design guidelines. The benefit of the Germani et al. method is that it can generate concrete and detailed design suggestions for the designer from the database, which is not possible to the same extent with the developed tool. Two disadvantages of the Germani et al. method are that its guidelines have a limited inclusion of RE measures and focus on the design of electronic and mechatronic products. A similar approach to creating a library of knowledge to solve problems is relational tables [69]. These are used in the GREENSYS tool, which is an expert system that aids engineers in the selection of designs for environmental methods and tools [69]. By answering questions such as "what principles apply for your design object?" and "which product life cycle would you like to impact?", among others, recommended guidelines are presented. This tool thus shares many similarities with REDIG; however, an important step for the user of the GREENSYS tool is selecting which part of the lifecycle needs to be improved. Hence, previous knowledge of hotspots may be required, which often entails a life cycle analysis.

Rossi, et al. [70] found several barriers and weaknesses regarding the tool by Germani, et al. [68] and similar tools that integrate eco-design methods in existing tools, such as CBR and PLM for industry implementation, e.g., the need to acquire experiences of the method's principles, training, time to apply the method, requirement for skilled staff, the complex and elaborate approaches, and license prices [70]. Based on the requirements from the designer, the developed tool must be easy to use and understand, which is why a spreadsheet-based tool was developed (Supplementary Materials, REDIG tool).

\subsubsection{Ranking}

The absence of a ranking of measures and no indications for improvements may be seen as a limitation of the developed tool since ranking measures is considered by many as an important feature of tools and methods [11]. For example, Moreno, et al. [71] included a ranking system of circular design strategies based on the subjective opinion of experts in circular economy and design. However, if their circular design tool had been used in the present study, design strategies, such as encouraging maintenance, allowing for reusability, and the ease of disassembly, would have been primarily suggested. This was not considered possible for the present product. Den Hollander, et al. [9] instead based their ranking of the inertia principle, which entails keeping the product in its original state for as long as possible. If their design method had been used, prolonged life would have been rated highly but the suggested change in materials would have been excluded.

There are two main reasons why ranking and indicating improvements were not included in the present tool. First, providing improvement potential or ranking on a general product level is very difficult since a measure could entail different aspects depending on the product and its lifecycle. 
For example, design for energy efficiency is accomplished by different means for a gasoline-powered vehicle than for an electric washing machine. The potential improvement of a measure thus depends on details such as the material content of the product, how and where the product and its materials are produced, user behavior, the type of energy system in place, etc. This also means that measures lead to trade-offs between environmental impacts. This is why we did not consider the ranking provided in the CE frameworks, such as the Ellen MacArthur Foundation (EMF) [3] and Potting, et al. [4], as meaningful for designers. These rankings are presumably only valid during ideal conditions, such as no losses, carbon-neutral energy systems, and efficient recycling systems. Second, a ranking of measures may not be sufficient since many measures can, and in some cases should, be combined. As pointed out in Böckin, et al. [15], irrespective of efforts to extend the use of products, post-use handling is required for replaced components and eventually disposed products. Measures for extending the use of products and recycling are thus complementary.

\subsubsection{Trade-Offs}

In this study, trade-offs, meaning when a sacrifice is made in one area to obtain benefits in another [11], concerned environmental and resource use in relation to different design considerations. Providing information about trade-offs is an aspect that has been asserted as important for increasing the usability of tools [72] and has been identified as a limitation in many design tools and methods [70]. One explanation could be that design methods can be created based on different assumptions and purposes. For example, some methods are based on assuming the waste hierarchy as largely beneficial [19], others are based on own experience in eco-design [60], whereas others have the objective of finding an optimal design, for instance, many of the designs for X (DfX) approaches [73]. Using DfX approaches is the base for many CE design methods, as in Moreno, et al. [10]. The fewer design methods for CE products seems to be directly based on empirical knowledge, such as LCA studies, even though many eco-design methods have originated from LCAs. LCAs can provide information about trade-offs along with a product's lifecycle and aid in the exploration as to whether and under which circumstances a measure can lead to RE [74]. Therefore, the developed tool informs about potential trade-offs and additional design considerations.

\subsubsection{Design Measures}

The third aspect that differentiates this tool from others is the inclusion of measures intended to improve user behavior. Moreno, et al. [10], who presented a conceptual framework for circular design, argued that "if a true circular design is applied, design will not need a palliative strategy to influence more sustainable behavior" [10] (p. 6). They also claimed that circular design considers the system as a whole, and that system thinking has the potential to enable a true adoption of circular design [10]. We think that system thinking in design will not automatically change user behavior. Design must aim for behavioral change to influence and change user behavior, as in Wever, et al. [37]. As highlighted by Wastling, et al. [17] (p. 15), "user behavior does have an impact and should therefore be considered and be designed for when relevant". To illustrate the potential of changing user behavior, Willskytt and Tillman [59] conducted an LCA study to investigate the impacts of ensuring that users use the correct variants of incontinence products for their needs. The result showed that most users used products two levels above the needed absorption capacity. A change in the appropriate absorption level of the products led to a $20 \%$ decrease in impact on global warming and resource use.

Therefore, the following design measures were considered with the goal of influencing the user behavior:

- Use effectively: user-centered design and design for sustainable behavior through information, functionality matching, eco-feedback, forced functionality, portion control, and enable using all of the product;

- Maintain, repair, remanufacture: error-proofed design to enable desired behavior and reduce mistakes during use; 
- Reduce the use of energy and auxiliary materials: eco-feedback;

- Increase lifespan of product: design for attachment and trust;

- Use for full technical lifespan: design for attachment, enable personalization and adaptability;

- Sharing: user-centered design in terms of understanding the requirements for sharing a product/willingness to share and error-proofed design; and

- Shift to multiple use: design for attachment.

The user's behavior influences the possibility of suitable post-use treatment. For instance, the user makes the decision to separate materials for recycling, take products to a recycling center, or notably, not putting it in general waste containers [17]. Nevertheless, it is not possible to design behavior; it is only possible to the influence people's ability to act with artifacts by designing for behavior [75].

\subsubsection{Product Types}

The last aspect that differs among the compared design methods is the type of products they address. There are typically two approaches to considering product types in design methods: non-product-specific and product-specific. The customization of non-product-specific guidelines in earlier literature required a necessary step to make them useful for companies. For instance, Luttropp and Brohammer [35] acknowledged that their guidelines must be customized to be directly useful in a company since guidelines must be product-specific. Much literature, however, does not provide any clear customization of non-product-specific methods [6,10,71]. Other product-specific methods for durable products $[7,9]$ seem to fall short on providing more detailed product-specific guidelines. Bovea and Perez-Belis [20] and Vezzoli [14], however, acknowledged that different product categories have different design constraints on design measures. Not providing customization or guidance makes a design method harder to use than a method that does, as in our tool, where recommendations are based on product characteristics.

Many of the studies focus on durable products in general [7,9,18,19], a specific durable product [20], or products in general $[6,10]$. Consumables, in contrast, have been somewhat forgotten in many of the circular design methods [76,77], with the exception of Haffmans, et al. [78]. One explanation for the tendency to address mainly durable products is that they can more easily be reused, repaired, remanufactured, and recirculated [18]. For this reason, knowledge about possible design measures and approaches that lead to resource efficiency for different types of consumables is important. This study can be seen as an effective attempt to cover the type of design considerations relevant for these products; however, more in-depth research is needed.

\subsection{Practical Contributions}

The practical contributions of the tool are summarized as follows. First, the tool does not require the user to have carried out an LCA of the product to identify its hotspots, which is often the prerequisite for other tools. Second, the tool potentially contributes to decreasing the time spent in the early stages of design by guiding the designer to relevant design measure(s) for their product. It is time-consuming to move forward with many concepts and to environmentally evaluate the different concepts. Third, the tool encourages the designer to visualize the whole lifecycle of the product. This is expected to enable lifecycle thinking and enables the designer to come up with improvements at different lifecycle stages. Fourth, the tool can be used as a learning tool about different aspects of resource efficiency that are relevant, not only for professionals in product development, but also for others within an organization. Finally, other proposed methods and tools often fail to report on the usability, usefulness, or similar characteristics as further evidence of the results of their application in industry. Therefore, having considered usefulness and usability in the tool can be seen as a contribution. 


\section{Conclusions}

In this study, we aimed to construct a design guideline tool to address the identified gaps in the existing circular design literature. The first gap addressed was that general rankings of measures do not consider real-world circumstances, such as low collection rates in recycling and losses in remanufacturing. It was argued that measures can be interdependent and work in sequence or parallel. For this reason, design methods are needed to provide information about relevant design guidelines based on product characteristics, as presented in the proposed tool (REDIG). Second, information about the trade-offs of different CE measures seems to be scarce in design tools. Therefore, the proposed tool describes the possible trade-offs of different measures. Third, CE seems limited in addressing user practice and behavior, which been often pointed out as necessary for the full exploitation of CE measures. Hence, determining how to influence user behavior is also addressed in the proposed tool. Fourth, design methods for the $\mathrm{CE}$ are often limited in the inclusion of design considerations suitable for both consumable and durable products, which are therefore addressed in the developed tool. Finally, previous literature demonstrated that most design methods are not applied in professional design practice. In response, the proposed design guideline tool was evaluated with a design case in terms of usability and usefulness. In this sense, REDIG contributes to the identified gaps, which, in our opinion, makes the tool novel.

The proposed design guideline tool is based on learnings from a large number of lifecycle-based assessment studies showing which different resource-efficient measures are suitable for which product characteristics. The tool was also evaluated in terms of usefulness through a comparative LCA. The results of the LCA showed that the tool led to a more resource-efficient product concept. Usability was also considered through a questionnaire answered by an experienced designer. The questionnaire showed that the designer was satisfied with the usability of the tool as well as its usefulness.

Although this paper provides findings for the practical implementation of resource efficiency, more research is required to determine the extent to which these conclusions are valid for other products and companies. Further research would further support the validity of the applicability of the tool in a larger context.

Supplementary Materials: The following are available online at http://www.mdpi.com/2071-1050/12/12/4953/s1, REDIG tool.

Author Contributions: Conceptualization, S.W. and S.A.B.-M.; Methodology, S.W. and S.A.B.-M.; Validation, S.W. and S.A.B.-M.; Formal analysis, S.W., Investigation, S.W.; Resources, S.W. and S.A.B.-M.; Data curation, S.W; Writing—original draft preparation, S.W.; Writing—-review and editing, S.W. and S.A.B.-M.; Visualization, S.W. and S.A.B.-M.; Project administration, S.W. and S.A.B.-M.; All authors have read and agreed to the published version of the manuscript.

Funding: This research was supported by Mistra REES (Resource-Efficient and Effective Solutions) and funded by Mistra (The Swedish Foundation for Strategic Environmental Research), grant number 2014/16, and Chalmers Area of Advance Production.

Acknowledgments: The authors wish to thank the case company for participation and the designer for input, time spent, and valuable feedback. Lastly, the authors wish to thank Professor Anne-Marie Tillman and Professor Tomohiko Sakao for their valuable feedback on earlier versions of this paper.

Conflicts of Interest: The authors declare no conflict of interest. The funders had no role in the design of the study; in the collection, analyses, or interpretation of data; in the writing of the manuscript, or in the decision to publish the results.

\section{Appendix A}

Figure A1 conveys the exercise where the designer qualitatively draws the material flows of the current product's lifecycle. This is done by mapping the main processes of the product lifecycle, from extraction of resources, across production and use, to post-use treatment. The purpose is to enable lifecycle thinking and to visualize the consequences of changes in the product system. 


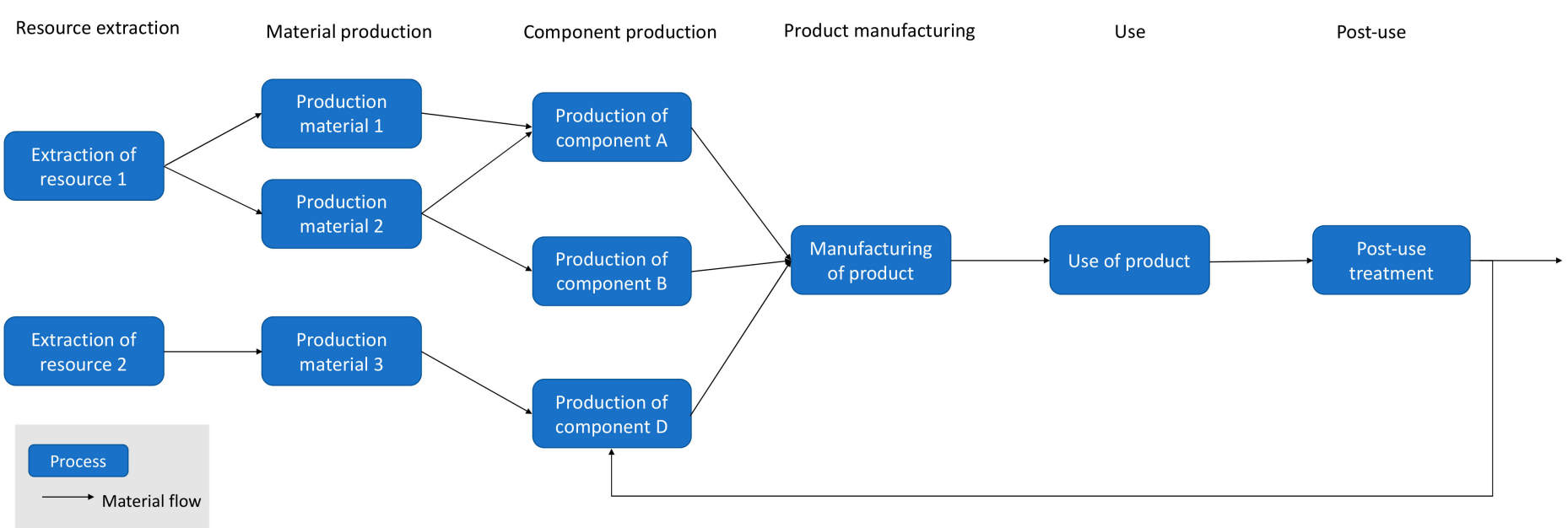

Figure A1. Example of drawing the material flow of a product's lifecycle. 
Table A1. Design guidelines for durable products related use phase.

\begin{tabular}{|c|c|c|c|c|c|}
\hline Product Characteristic & Example Products & $\begin{array}{c}\text { Recommended Design } \\
\text { Measure }\end{array}$ & Example Measures & $\begin{array}{c}\text { Potential Environmental } \\
\text { Trade-Offs }\end{array}$ & Design Considerations \\
\hline \multirow[b]{2}{*}{$\begin{array}{l}\text { Durable products, } \\
\text { irrespective of other } \\
\text { characteristics }\end{array}$} & \multirow[b]{2}{*}{$\begin{array}{l}\text { Machines, buildings, } \\
\text { vehicles, furniture, } \\
\text { household appliances, } \\
\text { electronics and } \\
\text { components } \\
\text { thereof, clothes }\end{array}$} & Use effectively & $\begin{array}{l}\text { Deliver/acquire only needed } \\
\text { function, use for intended } \\
\text { purpose, avoid losses } \\
\text { using use }\end{array}$ & No identified trade-offs & $\begin{array}{l}\text { User-centered design (understand how } \\
\text { the user will use the product) e.g., } \\
\text { functionality matching of user and } \\
\text { product by design products with only } \\
\text { needed function and not over-specifying }\end{array}$ \\
\hline & & $\begin{array}{l}\text { Maintain, repair, } \\
\text { remanufacture }\end{array}$ & $\begin{array}{l}\text { Maintain: inspect, maintain, } \\
\text { and protect before failure } \\
\text { Repair after wear, } \\
\text { malfunction, or failure } \\
\text { Remanufacture: restore } \\
\text { product to functional state } \\
\text { as good as new (or better) }\end{array}$ & $\begin{array}{c}\text { - Maintenance, repair, and } \\
\text { remanufacture can increase } \\
\text { transportation } \\
\text { - Products designed for } \\
\text { disassembly may use } \\
\text { more material } \\
\text { - Benefits of longer use vs. } \\
\text { impact from sensors } \\
\text { For active products with } \\
\text { technological development } \\
\text { towards use-phase efficiency: } \\
\text { - Use-phase efficiency vs. } \\
\text { benefits of use extension }\end{array}$ & $\begin{array}{l}\text { - Design for disassembly (particularly } \\
\text { important for complex products), e.g., } \\
\text { use standardized joins, minimize } \\
\text { connectors, modular design, use } \\
\text { fasteners instead of adhesives } \\
\text { - Design “out" the need for maintenance } \\
\text { by identifying possible failures and } \\
\text { through error proof design (user cannot } \\
\text { make mistakes) to reduce wear and tear } \\
\text { - Design maintenance system (e.g., for } \\
\text { energy efficiency, for preventive } \\
\text { maintenance, and for easy and } \\
\text { effective maintenance) }\end{array}$ \\
\hline $\begin{array}{l}\text { Durable products, } \\
\text { typically used for full } \\
\text { technical lifetime }\end{array}$ & $\begin{array}{c}\text { Vehicles, machines, } \\
\text { household appliances } \\
\text { and their } \\
\text { components, furniture }\end{array}$ & $\begin{array}{c}\text { Increase technical lifetime } \\
\text { by design }\end{array}$ & $\begin{array}{l}\text { Products and components } \\
\text { designed to last longer }\end{array}$ & $\begin{array}{l}\text { - Durability vs. amount } \\
\text { (or impact) of materials } \\
\text { For active products with } \\
\text { technological development } \\
\text { towards use-phase efficiency: } \\
\text { - Use-phase efficiency vs. } \\
\text { benefits of use extension }\end{array}$ & $\begin{array}{c}\text { - Design for durability (more material, } \\
\text { more robust material) } \\
\text { - Design for remanufacturing (make sure } \\
\text { the product can be remanufactured) } \\
\text { - Design for maintenance (improve the } \\
\text { maintenance of the product) } \\
\text { - Design for upgradability (make sure } \\
\text { that the product can be upgraded and } \\
\text { adapted to new needs of the user during } \\
\text { the lifetime. If the product is active, this } \\
\text { could be important to avoid trade-off } \\
\text { where an inefficient product (in terms of } \\
\text { energy use) is kept used for a long time }\end{array}$ \\
\hline
\end{tabular}


Table A1. Cont.

\begin{tabular}{|c|c|c|c|c|c|}
\hline Product Characteristic & Example Products & $\begin{array}{c}\text { Recommended Design } \\
\text { Measure }\end{array}$ & Example Measures & $\begin{array}{c}\text { Potential Environmental } \\
\text { Trade-Offs }\end{array}$ & Design Considerations \\
\hline $\begin{array}{l}\text { Durable products, } \\
\text { typically discarded } \\
\text { before being worn out }\end{array}$ & $\begin{array}{l}\text { Furniture, household } \\
\text { appliances, electronics, } \\
\text { clothes }\end{array}$ & $\begin{array}{l}\text { Use more of technical } \\
\text { lifetime, including reuse }\end{array}$ & $\begin{array}{l}\text { Use for longer by the same } \\
\text { user and/or second-hand } \\
\text { sales }\end{array}$ & $\begin{array}{l}\text { - Second-hand sales risk } \\
\text { inducing transportation } \\
\text { out-weighing benefits of reuse } \\
\text { For active products with } \\
\text { technological development } \\
\text { towards use-phase efficiency: } \\
\text { - Use-phase efficiency vs. } \\
\text { benefits of use extension }\end{array}$ & $\begin{array}{c}\text { Design to avoid non-technical } \\
\text { obsolescence: } \\
\text { - Timeless design (avoid fashion trends) } \\
\text { - Design for attachment: consumers exert } \\
\text { considerable influence upon product } \\
\text { lifespans, and may attach emotions to } \\
\text { products; promote quality } \\
\text { - Design for upgradability (e.g., modular } \\
\text { design or disassemble to upgrade } \\
\text { function or performance) } \\
\text { - Design for adaptability (possibility to } \\
\text { change design or functions during use) }\end{array}$ \\
\hline $\begin{array}{c}\text { Durable products, } \\
\text { typically discarded } \\
\text { before being worn out } \\
\text { and infrequently used }\end{array}$ & $\begin{array}{l}\text { Vehicles, washing } \\
\text { machines, tools, } \\
\text { clothes }\end{array}$ & Share & $\begin{array}{l}\text { Use regularly by several } \\
\text { users, e.g., clothes, library, } \\
\text { rented tools, communal } \\
\text { washing machines }\end{array}$ & $\begin{array}{l}\text { Sharing can increase } \\
\text { transportation for users } \\
\text { accessing the shared stock }\end{array}$ & $\begin{array}{l}\text { - Design for more robust and easier to } \\
\text { use product and uniform design } \\
\text { - Design for easy maintenance (e.g., } \\
\text { modular design or disassembly) } \\
\text { - User centered design (understand the } \\
\text { requirements for sharing a product) } \\
\text { - Error proof design (user cannot make } \\
\text { mistakes) to reduce wear and tear }\end{array}$ \\
\hline Durable products, active & $\begin{array}{l}\text { Machines, buildings, } \\
\text { vehicles, household } \\
\text { appliances, electronics } \\
\text { and active } \\
\text { components thereof } \\
\text { (for vehicles also } \\
\text { passive components) }\end{array}$ & $\begin{array}{l}\text { Reduce use of auxiliary } \\
\text { materials and energy } \\
\text { during use (use efficiently) }\end{array}$ & $\begin{array}{l}\text { Energy efficient machines, } \\
\text { vehicles, electronics, etc., } \\
\text { energy- and water-efficient } \\
\text { buildings and household } \\
\text { appliances, e.g., turn off } \\
\text { equipment when not in use, } \\
\text { eco-driving }\end{array}$ & $\begin{array}{l}\text { - Reduced use-phase impact vs. } \\
\text { increased production-phase } \\
\text { impact } \\
\text { - Reduced use-phase impact vs. } \\
\text { impact from sensors in cases } \\
\text { when required }\end{array}$ & $\begin{array}{c}\text { - Design for energy efficiency } \\
\text { - Design for reduced consumption of } \\
\text { auxiliary materials (e.g., water, } \\
\text { detergents, lubricants) } \\
\text { - Design for light weight (vehicles and } \\
\text { machines) } \\
\text { - Designs that promote efficient use of } \\
\text { auxiliary materials and energy use (e.g., } \\
\text { sensors and control units, eco-mode } \\
\text { programs, monitoring and information) } \\
\text { - Design for upgrading (if fast efficiency } \\
\text { development, this is important) }\end{array}$ \\
\hline $\begin{array}{l}\text { Durable products for } \\
\text { which function partly } \\
\text { remains when no longer } \\
\text { usable for } \\
\text { original purpose }\end{array}$ & $\begin{array}{l}\text { Automotive batteries, } \\
\text { electronics }\end{array}$ & Repurpose & $\begin{array}{l}\text { Reuse in a function other } \\
\text { than the original one, e.g., } \\
\text { reuse of automotive } \\
\text { batteries for stationary } \\
\text { energy storage }\end{array}$ & $\begin{array}{l}\text { For active products with } \\
\text { technological development } \\
\text { towards use-phase efficiency: } \\
\text { - Use-phase efficiency vs. } \\
\text { benefits of use extension }\end{array}$ & $\begin{array}{c}\text { - Design for disassembly } \\
\text { - Design for cascades (plan for second life } \\
\text { use of product/component) } \\
\text { - Communication of specification to } \\
\text { producer of repurposed product } \\
\text { important (e.g., mark components with } \\
\text { its content, provide information) }\end{array}$ \\
\hline
\end{tabular}


Table A2. Design guidelines for consumable products related the use phase.

\begin{tabular}{|c|c|c|c|c|c|}
\hline Product Characteristic & Example Products & $\begin{array}{c}\text { Recommended Design } \\
\text { Measure }\end{array}$ & Example Measure & $\begin{array}{c}\text { Potential Environmental } \\
\text { Trade-Offs }\end{array}$ & Design Considerations \\
\hline Dissipative products & $\begin{array}{l}\text { Food, fuels, water, } \\
\text { electricity, cleaning } \\
\text { agents }\end{array}$ & Use effectively & $\begin{array}{c}\text { Deliver only needed } \\
\text { function, avoid losses using } \\
\text { use (e.g., smart dispensing), } \\
\text { use for intended purpose, } \\
\text { increase functionality to } \\
\text { improve system efficiency } \\
\text { (e.g., detergents allowing } \\
\text { lower washing temperature } \\
\text { and fuel additive increasing } \\
\text { engine efficiency) }\end{array}$ & $\begin{array}{c}\text { - Reduced use-phase impact vs. } \\
\text { production of sensors in cases } \\
\text { when required } \\
\text { - Chemicals with higher } \\
\text { functionality vs. risk of more } \\
\text { hazardous constituents }\end{array}$ & $\begin{array}{c}\text { - Design for smart distribution: } \\
\text { - Packaging sizes } \\
\text { - Packaging shape (possibility to } \\
\text { empty packaging) } \\
\text { - Smart dispensing (e.g., foam soap) } \\
\text { - User-centered design (understand how } \\
\text { the user will use the product and how } \\
\text { resource waste can be reduced) } \\
\text { - Designs that promote effective use } \\
\text { (e.g., sensors and control units) } \\
\text { - Error-proof design (user cannot make } \\
\text { mistakes) and thus reduce losses }\end{array}$ \\
\hline \multirow[b]{2}{*}{ Disposable products } & \multirow{2}{*}{$\begin{array}{l}\text { Single-use items, e.g., } \\
\text { tissues, packaging, } \\
\text { hygiene products. } \\
\text { Disposable } \\
\text { components in } \\
\text { durable products, e.g., } \\
\text { ink cartridges, } \\
\text { single-use batteries, } \\
\text { disposable machine } \\
\text { components }\end{array}$} & Use effectively & $\begin{array}{c}\text { Deliver/acquire only needed } \\
\text { function, avoid losses using } \\
\text { use (e.g., smart dispensing), } \\
\text { use for intended purpose }\end{array}$ & $\begin{array}{l}\text { - Reduced use-phase impact vs. } \\
\text { production of sensors in cases } \\
\text { when required }\end{array}$ & $\begin{array}{c}\text { - User-centered design (understand how } \\
\text { the user will use the product and how } \\
\text { resource waste can be reduced) } \\
\text { - Designs that enable correct use } \\
\text { - User recommendations/ information } \\
\text { - Indicators for remaining level } \\
\text { - Smart dispensing (e.g., one napkin at } \\
\text { the time) } \\
\text { - Designs that promote effective use } \\
\text { (e.g., sensors and control units) } \\
\text { - Error-proof design (user cannot make } \\
\text { mistakes) and thus reduce losses }\end{array}$ \\
\hline & & $\begin{array}{l}\text { Shift to } \\
\text { multiple-use product }\end{array}$ & $\begin{array}{l}\text { Reusable, e.g., washable, } \\
\text { rechargeable, and } \\
\text { refillable products }\end{array}$ & $\begin{array}{l}\text { - Benefits from multiple use vs. } \\
\text { increased impact from } \\
\text { production and } \\
\text { maintenance/cleaning, } \\
\text { including transportation }\end{array}$ & $\begin{array}{l}\text { - Redesign for multiple use (more } \\
\text { durable product and handle } \\
\text { maintenance) } \\
\text { - Design for attachment: consumers exert } \\
\text { considerable influence upon product } \\
\text { lifespans, and may attach emotions to } \\
\text { products which ensures that the product } \\
\text { will be used for a long time; } \\
\text { promote quality } \\
\text { - Design for hygiene: the multiple-use } \\
\text { product feels and is hygienic to reuse } \\
\text { - Design maintenance system (energy } \\
\text { efficient both in terms of } \\
\text { maintenance activity) }\end{array}$ \\
\hline
\end{tabular}


Table A3. Design guidelines for all products related material selection and production.

\begin{tabular}{|c|c|c|c|}
\hline Recommended Design Measure & Example Measures & Potential Environmental Trade-Offs & Design Considerations \\
\hline $\begin{array}{l}\text { Reduce losses in production (including } \\
\text { valorizing by-product streams) }\end{array}$ & $\begin{array}{l}\text { Reduce scrap rates and other material } \\
\text { losses in production, increase energy } \\
\text { efficiency in production, valorize } \\
\text { by-product energy and material flows, } \\
\text { internally (process integration) or } \\
\text { externally (industrial symbiosis) }\end{array}$ & $\begin{array}{l}\text { - Reduced losses of material in production } \\
\text { vs. energy use for avoiding losses }\end{array}$ & $\begin{array}{c}\text { Design for manufacturing: } \\
\text { - Use operation materials with a long lifetime } \\
\text { - Increase the material and energy efficiency of } \\
\text { actions in the process, e.g., reduce losses due } \\
\text { to leakage. } \\
\text { - Close material and energy loops for } \\
\text { water, solvents } \\
\text { - Technology optimization (implement new } \\
\text { technologies, improve process control, } \\
\text { redesign processes) } \\
\text { - Industrial symbiosis (one industry' uses } \\
\text { another industry's waste/by-products } \\
\text { as resource) } \\
\text { Product design for reduced impact } \\
\text { in production: } \\
\text { - Avoiding complex product structure and many } \\
\text { details to reduce losses when cutting materials }\end{array}$ \\
\hline $\begin{array}{l}\text { Reduce material quantity in product } \\
\text { without material substitution }\end{array}$ & $\begin{array}{c}\text { Thinner layers of specific materials, } \\
\text { non-massive designs, e.g., truss and } \\
\text { shell structures }\end{array}$ & $\begin{array}{l}\text { - Risk for losing function, e.g., durability } \\
\text { - Benefit of removing water vs impact of } \\
\text { removing water for the concentrate }\end{array}$ & $\begin{array}{l}\text { - Dematerialization (use less material for a } \\
\text { specific function) } \\
\text { - “Take out water" to reduce packaging material } \\
\text { and impacts from transport } \\
\text { - Design out the need for packaging }\end{array}$ \\
\hline Change material in product & $\begin{array}{l}\text { Change to/increase share of: } \\
\text { - Bio-based material } \\
\text { - Bio-degradable material } \\
\text { - Recycled material } \\
\text { Substitute/decrease share of: } \\
\text { - Scarce materials } \\
\text { - Hazardous constituents }\end{array}$ & $\begin{array}{l}\text { - Risk for burden-shifting when substituting } \\
\text { material } \\
\text { - Changing material is often a precondition } \\
\text { for other measures, e.g., use-phase efficiency } \\
\text { or increased lifetime. Potential trade-off } \\
\text { between the benefits of the enabled measure } \\
\text { and impact of the new material }\end{array}$ & $\begin{array}{c}\text { - Consider recycling implications during } \\
\text { material selection: avoid hazardous materials; } \\
\text { make sure scarce/ critical are easily liberated in } \\
\text { recycling } \\
\text { - Products made from fossil-based } \\
\text { materials—change to bio-based } \\
\text { - Attention needed to where and how } \\
\text { biomaterial is cultivated and harvested to avoid } \\
\text { land use-related impacts } \\
\text { - Products that risk uncontrolled dispersion } \\
\text { (littering, dissipative use of consumables, } \\
\text { degradation of surfaces): use biodegradable and } \\
\text { non-hazardous materials }\end{array}$ \\
\hline
\end{tabular}


Table A4. Design guidelines for all products regarding the post-use phase.

\begin{tabular}{|c|c|c|c|c|}
\hline Product Characteristic & $\begin{array}{l}\text { Recommended Design } \\
\text { Measure }\end{array}$ & Useful Output & Potential Environmental Trade-Offs & Design Considerations \\
\hline $\begin{array}{l}\text { All products, except } \\
\text { consumables, used in a } \\
\text { dissipative manner. Relevant in } \\
\text { particular for products with } \\
\text { significant impacts from } \\
\text { material production }\end{array}$ & Recycle material & Recycled material & $\begin{array}{l}\text { - Impacts from recycling need to be } \\
\text { smaller than impacts from alternative } \\
\text { material production } \\
\text { - Risk of keeping hazardous substances } \\
\text { in circulation }\end{array}$ & $\begin{array}{c}\text { Design for recycling: } \\
\text { - Few or uniform materials (locate same } \\
\text { materials together) } \\
\text { - Avoid molding or fusing } \\
\text { incompatible materials } \\
\text { - Easily liberated materials, e.g., use snap } \\
\text { fits instead of adhesives } \\
\text { - Easy to disassemble (no adhesive) }\end{array}$ \\
\hline Biodegradable products & Digest anaerobically & $\begin{array}{c}\text { Biogas, } \\
\text { digestate (complete fertilizer } \\
\text { and soil enhancer) }\end{array}$ & $\begin{array}{l}\text { - Impacts from digestion need to be } \\
\text { smaller than avoided impact from } \\
\text { alternative production of its products } \\
\text { - Risk of keeping hazardous substances in } \\
\text { circulation }\end{array}$ & $\begin{array}{l}\text { Requires whole product to be made from } \\
\text { biodegradable materials, or/unless the } \\
\text { non-biological material is easy to } \\
\text { separate before treatment }\end{array}$ \\
\hline Biodegradable products & Compost & Soil enhancer & $\begin{array}{l}\text { - Impacts from composting need to be } \\
\text { smaller than avoided impact from } \\
\text { alternative production of its products } \\
\text { (e.g., soil enhancers) } \\
\text { - Risk of keeping hazardous substances in } \\
\text { circulation }\end{array}$ & $\begin{array}{l}\text { Requires whole product to be made from } \\
\text { biodegradable materials, or/unless the } \\
\text { non-biological material is easy to } \\
\text { separate before treatment }\end{array}$ \\
\hline Combustible products & Incinerate with energy recovery & Heat and/or electricity & $\begin{array}{l}\text { - Impacts from incineration need to be } \\
\text { smaller than avoided impact from } \\
\text { alternative production of its products }\end{array}$ & $\begin{array}{c}\text { - Strive for completely combustible } \\
\text { products to reduce slag } \\
\text { - Design for disassembly (separate parts } \\
\text { to recycle and parts to combust) } \\
\text { - Avoid hazardous metals (end up in flue } \\
\text { gases and slag) } \\
\text { - Avoid halogens (creates hazardous } \\
\text { flue gases) }\end{array}$ \\
\hline $\begin{array}{l}\text { Dissipatively used products, } \\
\text { collected as waste in sewers }\end{array}$ & Treat wastewater & $\begin{array}{c}\text { Biogas, } \\
\text { heat, } \\
\text { sludge containing plant } \\
\text { nutrients }\end{array}$ & $\begin{array}{l}\text { - Impacts from digestion need to be } \\
\text { smaller than avoided impact from } \\
\text { alternative production of its products } \\
\text { - Risk of introduction of hazardous } \\
\text { substances in the food chain } \\
\text { - Risk of dispersion of pathogens }\end{array}$ & $\begin{array}{c}\text { Design that make sure only things that } \\
\text { are supposed to end up in toilets end } \\
\text { up there }\end{array}$ \\
\hline $\begin{array}{l}\text { All products and/or residues } \\
\text { from other post-use processes }\end{array}$ & Landfill and control & $\begin{array}{l}\text { Landfill gas, } \\
\text { long term material source }\end{array}$ & $\begin{array}{l}\text { Landfill impacts versus sink for carbon, } \\
\text { materials, and hazardous substances }\end{array}$ & \\
\hline
\end{tabular}


Table A5. Definitions and examples of design measures.

\begin{tabular}{|c|c|c|}
\hline Design Measures & Definition & Sources \\
\hline Industrial symbiosis & $\begin{array}{l}- \text { Use by-products or waste from other companies as raw material } \\
\text { - Generate by-products or waste that can be reused as raw material by other companies } \\
\text { - Take advantage of other companies' utilities in the production process (share utilities, e.g., energy, heat, and steam) }\end{array}$ & Mantesea, et al. [50] \\
\hline Cleaner production & $\begin{array}{c}\text { Production efficiency through optimization of productive use of natural resources (materials, energy, water) at all } \\
\text { stages of the production cycle. General examples: } \\
\text { - Use less of hazardous raw, auxiliary, or operating materials } \\
\text { - Use operation materials with a longer lifetime } \\
\text { - Close material and energy loops for water, solvents, etc. } \\
\text { - Cascading of material and energy streams } \\
\text { - Increase the material and energy efficiency of actions in the process, e.g., reduce losses due to leakage } \\
\text { - Technology optimization (implement new technologies, improve process control, redesign processes) } \\
\text { Minimizing energy consumption during pre-production and production: } \\
\text { - Select materials with low energy intensity } \\
\text { - Select processing technologies with the lowest energy consumption possible } \\
\quad \text { - Use energy-efficient machinery } \\
\text { - Use the heat emitted in processes for preheating other determined process flows } \\
\text { - Engage pump and motor speed regulators with dynamic configuration } \\
\text { - Equip the machinery with smart power-off utilities } \\
- \text { Optimize the overall dimensions of engines } \\
- \text { Facilitate engine maintenance } \\
\text { - Define accurately the tolerance parameters } \\
\text { - Engage in efficient heating, illumination, and ventilation in buildings } \\
\text { dimensions of all transportable materials and semi-products }\end{array}$ & Vezzoli [14] \\
\hline $\begin{array}{l}\text { Design for manufacturing } \\
\text { and assembly }\end{array}$ & $\begin{array}{c}\text { Design for manufacture and assembly (DFMA) was born after design for manufacturing (DFM) and design for } \\
\text { assembly. DFA has been used by many companies around the world to develop product designs that use optimal } \\
\text { manufacturing and assembly processes. The development of DFMA started in the 1990s with research into automatic } \\
\text { assembly (DFA). The main goal is to minimize part count and reorientation of parts, standardize parts, encourage } \\
\text { modular design, emphasize top-down assemblies, design for component symmetry, design parts with self-aligning } \\
\text { and fastening features, and design parts for retrieval, handling, and insertion. Hence, DFA implies to: } \\
\text { - Minimize the number of components } \\
\text { - To simplify and reduce the number of manufacturing operations to use standard parts and materials } \\
\text { - To design for efficient joining, for ease of part fabrication, for ease of packaging, and for ease of assembly } \\
\text { - To use common parts across product lines, flexible components, and modular design } \\
\text { - To eliminate or reduce adjustment required }\end{array}$ & Benabdellah, et al. [49] \\
\hline
\end{tabular}


Table A5. Cont.

\begin{tabular}{|c|c|c|}
\hline Design Measures & Definition & Sources \\
\hline Dematerialization & Dematerialization can be accomplished by more efficient use of a given material for a given function. & Karlsson [51] \\
\hline Design for maintenance & $\begin{array}{l}\text { Enable ease of maintenance. The process of product maintenance ensures the smooth performance of equipment, } \\
\text { often at the cost of equipment downtime. Products that are easy to maintain, entail less downtime. } \\
\text { Some guidelines are: } \\
\text { - Accessibility: simplify access to and disassembly of components to be maintained. All equipment and } \\
\text { subassemblies that require routine inspections should be located such that they can be accessed in a readily and easy } \\
\text { manner. Additionally, they should be fitted with parts that can be connected rapidly to mechanical, air, electric, and } \\
\text { electronic connections. Avoid narrow slits and holes to facilitate access for cleaning } \\
\text { - Modularity: modularity requires grouping functionally similar parts into subassemblies, which then can be put } \\
\text { together to form the product. Prearrange and facilitate the substitution of short-lived components. Effective } \\
\text { modularization can be achieved only if interfaces are standard } \\
\text { - Simplicity: simpler designs are inherently easier to maintain. Simplicity can be achieved by reducing the number of } \\
\text { different parts or reducing the part variety } \\
\text { - Standardization: allows for the easy replacement of faulty components. It also assures designers of a certain } \\
\text { quality level } \\
\text { - Fool proofing: precautions should be devised to prevent fitting to the wrong assembly } \\
\text { - Inspectability: there should be an attempt to create a design that can be subjected to full, non-destructive, functional } \\
\text { testing. Equip products with diagnostic and/or auto-diagnostic systems for maintainable components } \\
\text { - Other: design products for easy on-site maintenance. Design complementary maintenance tools and documentation. } \\
\text { Design products that need less maintenance }\end{array}$ & $\begin{array}{c}\text { Chiu and Kremer [73], } \\
\text { Desai and Mital [40] } \\
\text { and } \\
\text { Vezzoli [14] }\end{array}$ \\
\hline Design for durability & $\begin{array}{l}\text { Designing for appropriate lifespan, e.g.: } \\
\text { - Design component with coherent lifespans, select the most appropriate materials and shapes to preserve } \\
\text { performance in relationship with the foreseen usage conditions } \\
\text { - Design equally useful lives for the different components } \\
\text { - Design the lifespan of replaceable components according to scheduled durability } \\
\text { - Enable separation of different components } \\
\text { - Select durable materials according to product performance and lifespan } \\
\text { Designing for reliability, e.g.: } \\
\text { - Reduce overall number of components } \\
\text { - Simplify products and eliminate weak links } \\
\text { - Facilitate upgrading and adaptability (see design for upgrading and design for adaptability) } \\
\text { - Facilitate maintenance (see design for maintenance) } \\
\text { - Facilitate reuse (see design for reuse) } \\
\text { - Facilitate repair and remanufacture (see design for remanufacturing) }\end{array}$ & Vezzoli [14] \\
\hline
\end{tabular}


Table A5. Cont.

\begin{tabular}{|c|c|c|}
\hline Design Measures & Definition & Sources \\
\hline Design for disassembly & $\begin{array}{c}\text { It is NOT the exact opposite or a reversal of the assembly process. Some proposed guidelines include: } \\
\text { - Product structure: create a modular design; minimize the component count; optimize component standardization; } \\
\text { minimize product variants } \\
\text { - Materials: minimize the use of different materials; use recyclable materials; eliminate toxic or hazardous materials } \\
\text { - Fasteners, joints and connections: minimize the number of joints and connections; make joints visible and accessible; } \\
\text { eliminate hidden joints; use joints that are easy to disassemble; mark non-obvious joints; use fasteners rather } \\
\text { than adhesives } \\
\text { - Characteristics of components for disassembly: good accessibility, low weight; robust; minimize fragile parts; } \\
\text { non-hazardous; preferably unpainted } \\
\text { - Disassembly conditions: design for automated disassembly; eliminate the need for specialized disassembly } \\
\text { procedures; Design for disassembly with simple and standard tools }\end{array}$ & Bogue [38] \\
\hline $\begin{array}{l}\text { Design for } \\
\text { remanufacturing }\end{array}$ & $\begin{array}{r}\text { The usual product activities are: clean core, strip core (disassembly), clean components, remanufacture components, } \\
\text { store components, build product (assembly), and test product } \\
\text { Product features and guidelines facilitating remanufacturing: } \\
\text { - Smooth surfaces } \\
\text { - Corrosion resistance. However, this will depend on the materials, as some coating materials may peel, leaving } \\
\text { debris that may damage components } \\
\text { - Non-adhesive surfaces. However, it may be difficult to maintain the integrity of such surfaces } \\
\text { - Design for excessive use of material for easily deteriorating surfaces } \\
\text { - Design and facilitate the removal and substitution of easily expendable components, e.g., threaded fasteners and } \\
\text { "breakable snap fits" } \\
\text { - Design structural parts that can be easily separated from external/visible ones, e.g., through modularity } \\
\text { - Novel disassembly techniques, e.g., soluble or shape memory fasteners } \\
\text { - Easy to replace degrading elements to better deal with mechanical wear and aesthetic damage } \\
\text { - Standard parts, ease of component condition identification and parts with "extra material" for rework and } \\
\text { cascading parts } \\
\text { - Provide easier access to components to be re-manufactured } \\
\text { - Calculate accurate tolerance parameters for easily expendable connections } \\
\text { - Design for excessive use of materials in places more subject to deterioration }\end{array}$ & $\begin{array}{c}\text { Ijomah, et al. [39] and } \\
\text { Vezzoli [14] }\end{array}$ \\
\hline Design for upgrading & $\begin{array}{l}\text { Products that fast become technologically obsolete can maintain their validity (remain in usage) by means of } \\
\text { exchanging the parts that have become obsolete. Upgrading leaves the product up to date with technology but saves } \\
\text { many components that do not have to be substituted } \\
\text { - Enable and facilitate software and hardware upgrading } \\
\text { - Design products that are upgradeable and adaptable onsite } \\
\text { - Design complementary tools and documentation for product upgrading and adaptation }\end{array}$ & Vezzoli [14] \\
\hline
\end{tabular}


Table A5. Cont.

\begin{tabular}{|c|c|c|}
\hline Design Measures & Definition & Sources \\
\hline $\begin{array}{l}\text { Design for energy } \\
\text { efficiency }\end{array}$ & $\begin{array}{l}\text { Design to reduce energy consumption during production and use by using more energy efficient components (light } \\
\text { weight for vehicles) and processes, to ensure rapid warm up and power down } \\
\text { - Minimize energy consumption during pre-production and production (see Cleaner production) } \\
\text { - Minimize energy consumption during transportation and storage (design compact products with high storage } \\
\text { density; scale down product and packaging weight; design concentrated products; equip products with } \\
\text { on-site assembly) } \\
\text { - Select the most efficient energy consumption systems during use } \\
\text { - Enable a variable consumption of energy, to follow demand fluctuations } \\
\text { - Minimize energy consumption during product development }\end{array}$ & $\begin{array}{c}\text { Arnette, et al. [44] and } \\
\text { Vezzoli [14] }\end{array}$ \\
\hline Design for adaptability & $\begin{array}{c}\text { Adaptability is understood in relation to the changing environment in which the product could be working } \\
\text { continuously, as well as the various stages of physical and cultural evolution of individuals. Because of this, it is } \\
\text { sound to design the products to be flexible, modular, and with dynamical dimensions, performance, and aesthetics. } \\
\text { - Design modular and dynamically configured products to facilitate their adaptability for changing environments } \\
\text { - Design multifunctional and dynamically configured products to facilitate their adaptability for the changing of } \\
\text { individuals' cultural and physical backgrounds } \\
\text { - Design products that are upgradeable and adaptable onsite } \\
\text { - Design complementary tools and documentation for product upgrading and adaptation }\end{array}$ & Vezzoli [14] \\
\hline User-centered design & $\begin{array}{l}\text { Based on Norman's psychology of design, the following are some guidelines for products that are easy to use: } \\
\text { - Build conceptual models, write manuals that are easily understood and that are written before the design } \\
\text { is implemented } \\
\text { - Make things visible: the user should be able to figure out the use of an object by seeing the right buttons or devices } \\
\text { for executing an operation } \\
\text { - Get the mappings right. One way to make things understandable is to use graphics. } \\
\text { thing to do order to give the user the feeling that there is one } \\
\text { - Exploit the power of constraints, both natural and artificial, in or of } \\
\text { - Design for error. Plan for any possible error that can be made, this way the user will be allowed the option of } \\
\text { recovery from any possible error made. Design mistake prevention into the process. Design mistake detection into } \\
\text { the process. Design the process to fail safely. Design a work environment that prevents errors } \\
\text { - When all else fails, standardize. Create an international standard if something cannot be designed without } \\
\text { arbitrary mappings } \\
\text { Error-proof design, also called "poka-yoke", } \\
\text { means reducing the potential for mistakes during use, thus reducing wear and tear, and ultimately repair and } \\
\text { maintenance by: } \\
\text { - Lock-ins, lockouts, and interlocks to prevent errors from occurring and by making it difficult to proceed until an } \\
\text { error has been corrected } \\
\text { - Warnings such as lights, information displays, and reminders that inform users of errors and desired behavior }\end{array}$ & $\begin{array}{l}\text { Abras, et al. [46] } \\
\text { Lockton, et al. [41] }\end{array}$ \\
\hline
\end{tabular}


Table A5. Cont.

\begin{tabular}{|c|c|c|}
\hline Design Measures & Definition & Sources \\
\hline $\begin{array}{l}\text { Design for sustainable } \\
\text { behavior }\end{array}$ & $\begin{array}{l}\text { For design for sustainable behavior: } \\
\text { - Motivating behavior: motivating users to change behavior by education, incentives, and changing attitudes } \\
\text { - Enabling behavior: enabling "desirable" behavior by making it easier for the user than the alternatives } \\
\text { - Constraining behavior: constraining users to "desirable" behavior by making alternatives difficult or impossible } \\
\text { - Make it easier for people to adopt a desired behavior } \\
\text { - Make it harder for people to perform undesired behavior } \\
\text { - Make people want a desired behavior } \\
\text { - Make people not want an undesired behavior } \\
\text { matching and behavior adaptation: } \\
\text { Thus, there are two main approaches to reduce environmental impacts during the use phases of functionality } \\
\text { - Functionality matching: aims at eliminating mismatches between delivered functionalities and desired } \\
\text { unctionalities. Redundant functionalities have an unnecessary impact, while missing functionalities can trigger } \\
\text { - Behavior adaptation by eco-feedback, scripting and forced functionality } \\
\text { Eco-feedback: the user is presented with specific information on the impact of his or her current behavior, and it is } \\
\text { left to the user to relate this information to his or her own behavior, and adapt this behavior, or not. } \\
\text { Scripting: the product is designed in such a way that the design triggers the sustainable use by either creating } \\
\text { hinderances for unsustainable use, or by making sustainable behavior so easy, it is performed almost without } \\
\text { thinking about it by the user. } \\
\text { Forced functionality: refers to either intelligent products that adapt automatically to changing circumstances, or to } \\
\text { designing in strong hinderances to prevent unsustainable behavior. }\end{array}$ & $\begin{array}{l}\text { Niedderer, et al. [47] } \\
\text { Wever, et al. [37] }\end{array}$ \\
\hline Design for attachment & $\begin{array}{l}\text { This is also called emotionally durable design, which strengthens the relationship between user and product to } \\
\text { increase the product lifetime. Design products that evoke enjoyment, or facilitate the formation of associations } \\
\text { between products and people, places, or events (memories): } \\
\text { - Designs that enable product personalization } \\
\text { - Designing products that age with dignity } \\
\text { - Designs that allow the user to capture memories }\end{array}$ & $\begin{array}{l}\text { Ceschin and } \\
\text { Gaziulusoy [16] }\end{array}$ \\
\hline Design for reuse & $\begin{array}{c}\text { Reuse of a product "as-is" or harvesting working parts and components for reuse: } \\
\text { - Increase the resistance of easily damaged and expendable components } \\
\text { - Arrange and facilitate access to and removal of retrievable components } \\
\text { - Design modular and replaceable components } \\
\text { - Design components according to standards to facilitate substitution } \\
\text { - Design reusable auxiliary parts } \\
\text { - Design refillable and re-usable packaging } \\
\text { - Design products for secondary use }\end{array}$ & Vezzoli [14] \\
\hline
\end{tabular}


Table A5. Cont.

\begin{tabular}{|c|c|c|}
\hline Design Measures & Definition & Sources \\
\hline Design for cascades & $\begin{array}{l}\text { Adopting a cascade approach means pre-planning and designing the route of the component or material from one } \\
\text { product or component to another, each with lower requirements. This strategy is based on the presupposition that, } \\
\text { in comparison with primary raw materials, the recycled materials will inevitably lose some of their characteristics, } \\
\text { either for economic or technological reasons. Therefore, we can imagine a route for cyclical recycling where materials } \\
\text { are employed for components with gradually lower requirements. }\end{array}$ & Vezzoli [14] \\
\hline Design for recycling & $\begin{array}{l}\text { These guidelines affect the efficiency of the recycling process. They must be integrated in the conceptual design stage } \\
\text { and applied simultaneously with the requirements of manufacturing, maintainability, reliability, and other design } \\
\text { objectives. Some of the guidelines include: } \\
\text { - Criteria regarding individual components and materials: avoid hazardous and otherwise environmentally harmful } \\
\text { materials. Avoid materials and components incompatible with standard recycling processes. Prefer materials that can } \\
\text { be reutilized easily. Allow for the reuse of recycled components. Minimize the number of different incompatible } \\
\text { materials. Select materials that easily recover after recycling the original performance characteristics. Avoid } \\
\text { composite materials or, when necessary, choose easily recyclable ones. Engage geometrical solutions, like ribbing, } \\
\text { to increase polymer stiffness instead of reinforcing fibers } \\
\text { - Criteria regarding disassembly operations: use joining elements that are easy to disassemble between subassemblies } \\
\text { consisting of incompatible materials. Design easily accessible joining elements. Protect joining elements from } \\
\text { corrosion and wear. Avoid the need of destructive disassembly techniques if they produce sharp edges. } \\
\text { Facilitate cleaning } \\
\text { - Criteria regarding the product as a whole: minimize the variety of materials. Minimize the number and variety } \\
\text { of joining } \\
\text { - Criteria relevant to logistics: provide information relevant to recycling, for example, material content, disassembly } \\
\text { procedures, available recycling options and processes, etc. Design the product in a way that it can be transported } \\
\text { easily after usage, i.e., by allowing pre-disassembly. Encourage the consumers to begin the recycling process. } \\
\text { Facilitate end-of-life collection and transportation. } \\
\text { - Adopt the cascade approach: design by taking into consideration the secondary use of the materials once recycled. } \\
\text { Arrange and facilitate the recycling of materials into components with lower mechanical requirements. Arrange and } \\
\text { facilitate the recycling of materials into components with lower aesthetical requirements. Arrange and facilitate } \\
\text { energy recovery from materials throughout combustion. }\end{array}$ & $\begin{array}{c}\text { Kriwet, et al. [53] and } \\
\text { Vezzoli [14] }\end{array}$ \\
\hline Product service system & $\begin{array}{l}\text { An integrated product and service offering that delivers value in use through customized solutions. For example, } \\
\text { power by the hour, where a user pays for the outcome of a solution. }\end{array}$ & Vezzoli [14] \\
\hline
\end{tabular}




\section{Appendix B}

\section{Appendix B1. Feedback from the Designer}

During the case study, the designer provided feedback during meetings and workshops. This allowed for more detailed development of the tool, as an emphasis was put on its usefulness and usability. The tool was validated through several iterations and according to feedback, mainly from the designer, who was the user of the tool. It was suggested that the tool could be more visual, structured, and provide more information. A generic material flow was later proposed to better visualize the impact of design suggestions and emphasize life cycle thinking. Moreover, more detailed descriptions and definitions were also provided to go along the guideline's question tree. The tree was also structured in a way so that it could be more logical and easier to go back and forth between the tree and the design suggestions. The designer, as the user of the tool, provided information also about the usefulness and usability of the tool.

\section{Appendix B2. Questionnaire for Evaluating Design Guideline Tool}

\section{Questions before using the tool}

1) How important is sustainability in your work?

Not important, Slightly important, Important, Very important, Extremely important.

2) How important is resource efficiency/circular economy in your work?

Not important, Slightly important, Important, Very important, Extremely important.

3) How many years have you been working with design?

4) How many years have you been working with eco-design?

5) What type of tools (both eco-design and others) do you usually use in your current work?

6) In short, how does your current process of developing a new product concept look like?

7) If you are to develop a more sustainable and resource efficient product concept, how do you usually decide which concept to go for?

\section{Questions after using the tool}

1) How familiar were you with the design recommendations?

Not familiar at all, Somewhat familiar, Familiar, Very familiar, Extremely familiar.

2) How informed were you about the trade-offs?

Not informed at all, Somewhat informed, Informed, Very informed, Extremely informed.

3) How relevant were the design recommendations?

Not relevant at all, Slightly relevant, Relevant, Very relevant, Extremely relevant.

If not relevant at all, what was not relevant and what was missing?

4) How satisfied are you with the generated solution concepts from the application of the tool?

Not satisfied at all, Somewhat Satisfied, Satisfied, Very satisfied, Extremely satisfied.

5) What were your expectations?

6) How easy was it to understand the tool during use? 
Not easy at all, Somewhat easy, Easy, Very easy, Extremely easy.

If not easy at all, what was difficult and what could be improved?

7) How understandable were the design recommendations?

Not understandable at all, Somewhat understandable, Understandable, Very understandable Extremely understandable.

If not understandable at all, what was difficult and what could be improved?

8) How understandable were the trade-offs?

Not understandable at all, Somewhat understandable, Understandable, Very understandable, Extremely understandable.

If not understandable at all, what was difficult and what could be improved?

9) How likely is it for you to incorporate the tool in your common design practice?

Not likely at all, Slightly likely, Likely, Very likely, Extremely likely.

If not likely at all, why not? What is missing, needed?

\section{Appendix B3. Tool Evaluation: Before Use}

The first part of the questionnaire was used to assess how familiar the designer was with sustainability and resource efficiency as well as the designer's general experience and use of support when designing. It was found that sustainability and resource efficiency was very important for the designer's professional practice. The designer had more than 30 years of general experience and had worked with eco-design-related issues for 20 years. Tools used in the designer's practice included LCA and other business-related ones, mainly intended to attract new customers. Making decisions on correct product design was, according to the designer, based mainly on costs, LCA results, material savings, and using tools such as the Pugh matrix.

\section{References}

1. Meadows, D.H.; Meadows, D.L.; Randers, J.; Behrens, W.W., III. Limits to Growth; Universe Books: New York, NY, USA, 1972; Volume 102.

2. Ghisellini, P.; Cialani, C.; Ulgiati, S. A review on circular economy: The expected transition to a balanced interplay of environmental and economic systems. J. Clean. Prod. 2016, 114, 11-32. [CrossRef]

3. EMF. Towards the Circular Economy. Economic and Business Rationale for an Accelerated Transition; Ellen MacArthur Foundation: Cowes, UK, 2013.

4. Potting, J.; Hekkert, M.; Worrell, E.; Hanemaaijer, A. Circular Economy: Measuring Innovation in the Product Chain; PBL Publishers: The Hague, The Netherlands, 2017.

5. Reike, D.; Vermeulen, W.J.V.; Witjes, S. The circular economy: New or Refurbished as CE 3.0?-Exploring Controversies in the Conceptualization of the Circular Economy through a Focus on History and Resource Value Retention Options. Resour. Conserv. Recycl. 2018, 135, 246-264. [CrossRef]

6. EMF the Circular Design Guide. Available online: https://www.circulardesignguide.com/ (accessed on 20 November 2019).

7. Pozo Arcos, B.; Balkenende, A.R.; Bakker, C.A.; Sundin, E. Product Design for a Circular Economy: Functional Recovery on Focus. In Proceedings of the DESIGN 2018 15th International Design Conference, Dubrovnik, Croatia, 21-24 May 2018; pp. 2727-2738.

8. Bocken, N.M.P.; de Pauw, I.; Bakker, C.; van der Grinten, B. Product design and business model strategies for a circular economy. J. Ind. Prod. Eng. 2016, 33, 308-320. [CrossRef]

9. Den Hollander, M.C.; Bakker, C.A.; Hultink, E.J. Product Design in a Circular Economy: Development of a Typology of Key Concepts and Terms. J. Ind. Ecol. 2017, 21, 517-525. [CrossRef]

10. Moreno, M.; De los Rios, C.; Rowe, Z.; Charnley, F. A Conceptual Framework for Circular Design. Sustainability 2016, 8, 937. [CrossRef] 
11. Byggeth, S.; Hochschorner, E. Handling trade-offs in Ecodesign tools for sustainable product development and procurement. J. Clean. Prod. 2006, 14, 1420-1430. [CrossRef]

12. Ljunggren Söderman, M.; André, H. Effects of circular measures on scarce metals in complex products-Case studies of electrical and electronic equipment. Resour. Conserv. Recycl. 2019, 151, 104464. [CrossRef]

13. Blomsma, F.; Brennan, G. The Emergence of Circular Economy: A New Framing Around Prolonging Resource Productivity. J. Ind. Ecol. 2017, 21, 603-614. [CrossRef]

14. Vezzoli, C. Design for Environmental Sustainability, Life Cycle Design of Products; Springer: Berlin, Germany, 2018.

15. Böckin, D.; Willskytt, S.; André, H.; Tillman, A.-M.; Ljunggren Söderman, M. How product characteristics can guide measures for resource efficiency-A synthesis of assessment studies. Resour. Conserv. Recycl. 2020, 154C, 104582. [CrossRef]

16. Ceschin, F.; Gaziulusoy, I. Evolution of design for sustainability: From product design to design for system innovations and transitions. Des. Stud. 2016, 47, 118-163. [CrossRef]

17. Wastling, T.; Charnley, F.; Moreno, M. Design for Circular Behaviour: Considering Users in a Circular Economy. Sustainability 2018, 10, 1743. [CrossRef]

18. Bakker, C.; den Hollander, M.; Van Hinte, E.; ZljLstra, Y. Products that Last: Product Design for Circular Buisness Models; TU Delft Library: Delft, The Netherlands, 2014.

19. Bakker, C.; Wang, F.; Huisman, J.; den Hollander, M. Products that go round: Exploring product life extension through design. J. Clean. Prod. 2014, 69, 10-16. [CrossRef]

20. Bovea, M.D.; Perez-Belis, V. Identifying design guidelines to meet the circular economy principles: A case study on electric and electronic equipment. J. Environ. Manag. 2018, 228, 483-494. [CrossRef]

21. Telenko, C.; Seepersad, C.; Webber, M. A compilation of design for environment principles and guidelines. In Proceedings of the ASME 2008 International Design Engineering Technical Conferences \& Computers and Information in Engineering Conference, Brooklyn, NY, USA, 3-6 August 2008.

22. Baumann, H.; Boons, F.; Bragd, A. Mapping the green product development field: Engineering, policyand business perspectives. J. Clean. Prod. 2002, 10, 409-425. [CrossRef]

23. Lofthouse, V. Ecodesign tools for designers: Defining the requirements. J. Clean. Prod. 2006, 14, 1386-1395. [CrossRef]

24. Lindahl, M. Engineering designers' experience of design for environment methods and tools-Requirement definitions from an interview study. J. Clean. Prod. 2006, 14, 487-496. [CrossRef]

25. Vallet, F.; Eynard, B.; Millet, D. Requirements and features clarifying for eco-design tools. In Global Product Development; Bernard, A., Ed.; Springer: Berlin/Heidelberg, Germany, 2011.

26. Dekoninck, E.A.; Domingo, L.; O’Hare, J.A.; Pigosso, D.C.A.; Reyes, T.; Troussier, N. Defining the challenges for ecodesign implementation in companies: Development and consolidation of a framework. J. Clean. Prod. 2016, 135, 410-425. [CrossRef]

27. Dickson, G.; Stolterman, E. Why Design Method Development is Not Always Carried Out as User-Centered Design. In Proceedings of the CHI Conference on Human Factors in Computing Systems, San Jose, CA, USA, 7-12 May 2016; pp. 4056-4060.

28. ISO. Environmental Management_Life Cycle Assessment-Principles and Framework; ISO 14040:2006; International Organization for Standardization: Geneva, Switzerland, 2006.

29. Kjaer, L.L.; Pigosso, D.C.A.; Niero, M.; Bech, N.M.; McAloone, T.C. Product/Service-Systems for a Circular Economy: The Route to Decoupling Economic Growth from Resource Consumption? J. Ind. Ecol. 2019, 23, 22-35. [CrossRef]

30. Bhamra, T.A.; Evans, S.; McAloone, T.C.; Simon, M.; Poole, S.; Sweatman, A. Integrating environmental decisions into the product development process. In I. The early stages. In Proceedings of the First International Symposium on Environmentally Conscious Design and Inverse Manufacturing, Tokyo, Japan, 1-3 February 1999; IEEE: Tokyo, Japan, 1999; pp. 329-333.

31. Tillman, A.-M.; Willskytt, S.; Böckin, D.; Andre, H.; Ljunggren Soderman, M. What circular economy measures fit what kind of product. In Draft Chapter in Handbook on the Circular Economy; Brandão, M., Lazaveric, D., Finnveden, G., Eds.; Edward Elgar Publishing Ltd.: Cheltenham, UK, 2020. 
32. Schöggl, J.-P.; Baumgartner, R.J.; Hofer, D. Improving sustainability performance in early phases of product design: A checklist for sustainable product development tested in the automotive industry. J. Clean. Prod. 2017, 140, 1602-1617. [CrossRef]

33. Poulikidou, S.; Björklund, A.; Tyskeng, S. Empirical study on integration of environmental aspects into product development: Processes, requirements and the use of tools in vehicle manufacturing companies in Sweden. J. Clean. Prod. 2014, 81, 34-45. [CrossRef]

34. Brambila-Macias, S.A.; Sakao, T.; Lindahl, M. Requirements for REES Design Support: A Survey among Large Companies and SMEs; Linköping University Electronic Press: Linköping, Sweden, 2018.

35. Luttropp, C.; Brohammer, G. EcoDesign Roadmap, 1st ed.; Studentlitteratur: Lund, Sweden, 2014.

36. Brezet, H.; van Hemel, C. Ecodesign: A Promising Approach to Sustainable Production and Consumption; UNEP: Paris, France, 1997.

37. Wever, R.; van Kuijk, J.; Boks, C. User-centred design for sustainable behaviour. Int. J. Sustain. Eng. 2008, 1, 9-20. [CrossRef]

38. Bogue, R. Design for disassembly: A critical twenty-first century discipline. Assem. Autom. 2007, 27, $285-289$. [CrossRef]

39. Ijomah, W.L.; McMahon, C.A.; Hammond, G.P.; Newman, S.T. Development of design for remanufacturing guidelines to support sustainable manufacturing. Robot. Comput.-Integr. Manuf. 2007, 23, 712-719. [CrossRef]

40. Desai, A.; Mital, A. Design for maintenance: Basic concepts and review of literature. Int. J. Prod. Dev. 2006, 3, 77-121. [CrossRef]

41. Lockton, D.; Harrison, D.; Stanton, N. Making the user more efficient: Design for sustainable behaviour. Int. J. Sustain. Eng. 2008, 1, 3-8. [CrossRef]

42. Selvefors, A.; Rexfelt, O.; Renström, S.; Strömberg, H. Use to use-A user perspective on product circularity. J. Clean. Prod. 2019, 223, 1014-1028. [CrossRef]

43. Mont, O. Reducing Life-Cycle Environmental Impacts through Systems of Joint Use. Green. Manag. Int. 2004, 2004, 63-77. Available online: https://www.jstor.org/stable/greemanainte.45.63 (accessed on 16 June 2020). [CrossRef]

44. Arnette, A.N.; Brewer, B.L.; Choal, T. Design for sustainability (DFS): The intersection of supply chain and environment. J. Clean. Prod. 2014, 83, 374-390. [CrossRef]

45. Allwood, J.M.; Ashby, M.F.; Gutowski, T.G.; Worrell, E. Material efficiency: A white paper. Resour. Conserv. Recycl. 2011, 55, 362-381. [CrossRef]

46. Abras, C.; Maloney-Krichmar, D.; Preece, J. User-centered design. In Encyclopedia of Human-Computer Interaction; Bainbridge, W., Ed.; Sage Publications: Thousand Oaks, CA, USA, 2004; Volume 37, pp. 445-456.

47. Niedderer, K.; Cain, R.; Clune, S.; Lockton, D.; Ludden, G.; Mackrill, J.; Morris, A. Creating Sustainable Innovation through Design for Behaviour Change: Full Project Report; University of Wolverhampton: Wolverhampton, UK, 2014.

48. Lilley, D.; Lofthouse, V.; Bhamra, T. Towards instinctive sustainable product use. In Proceedings of the 2nd International Conference in Sustainability, Creating the Culture, Aberdeen, UK, 2-4 November 2005.

49. Benabdellah, A.C.; Bouhaddou, I.; Benghabrit, A.; Benghabrit, O. A systematic review of design for X techniques from 1980 to 2018: Concepts, applications, and perspectives. Int. J. Adv. Manuf. Technol. 2019, 102, 3473-3502. [CrossRef]

50. Mantesea, G.; Bianchia, M.; Amarala, D. The industrial symbiosis in the product development: An approach through the DFIS. In Procedia Manufacturing, Proceedings of the Manufacturing Engineering Society International Conference 2017, MESIC 2017, Vigo, Spain, 28-30 June; Elsevier: Amsterdam, The Netherlands, 2018; Volume 21, pp. 862-886.

51. Karlsson, S. Man and Materials Flows, Towards Sustainable Materials Management; Sessions of the series A Sustainable Baltic Region; Umeå Universitet: Umeå, Sweden, 1997.

52. Napper, I.E.; Thompson, R.C. Environmental Deterioration of Biodegradable, Oxo-biodegradable, Compostable, and Conventional Plastic Carrier Bags in the Sea, Soil, and Open-Air Over a 3-Year Period. Environ. Sci. Technol. 2019, 53, 4775-4783. [CrossRef] [PubMed]

53. Kriwet, A.; Zussman, E.; Seliger, G. Systematic integration of design-for-recycling into product design. Int. J. Prod. Econ. 1995, 38, 15-22. [CrossRef] 
54. Jönsson, H.; Eklind, Y.; Albihn, A.; Jarvis, Å.; Kylin, H.; Nilsson, M.-L.; Nordberg, Å.; Pell, M.; Schnürer, A.; Schönning, C.; et al. Samhällets organiska avfall—en resurs i kretsloppet. Fakta Jordbr. Sammanfattar Aktuell Forsk. 2003, 1, 1-8.

55. Salomon, E. Fakta om Komposterat Eller Rötat Matavfall som Fosforgödselmedel. SLU Nyh. 2016. Available online: https://www.slu.se/ew-nyheter/2016/9/fakta-om-komposterat-eller-rotat-matavfall-somfosforgodselmedel/ (accessed on 16 June 2020).

56. Ecoinvent Ecoinvent 3.5. Available online: https://www.ecoinvent.org/database/older-versions/ecoinvent-35/ ecoinvent-35.html (accessed on 16 January 2020).

57. Ciroth, A. ICT for environment in life cycle applications openLCA-A new open source software for life cycle assessment. Int. J. Life Cycle Assess. 2007, 12, 209-210. [CrossRef]

58. Goedkoop, M.; Heijungs, R.; de Schryver, A.; Struijs, J.; van Zelm, R. ReCiPe 2008-A Life Cycle Impact Assessment Method which Comprises Harmonized Category Indicators at the Midpoint and the Endpoint Level/Report I: Characterisation; Ministerie van VROM: Den Haag, The Netherlands, 2009.

59. Willskytt, S.; Tillman, A.-M. Resource efficiency of consumables-Life cycle assessment of incontinence products. Resour. Conserv. Recycl. 2019, 144, 13-23. [CrossRef]

60. Luttropp, C.; Lagerstedt, J. EcoDesign and The Ten Golden Rules: Generic advice for merging environmental aspects into product development. J. Clean. Prod. 2006, 14, 1396-1408. [CrossRef]

61. Ameri, F.; Dutta, D. Product Lifecycle Management: Closing the Knowledge Loops. Comput. Aided Des. Appl. 2005, 2, 577-590. [CrossRef]

62. Yousnadj, D.; Jouanne, G.; Maranzana, N.; Segonds, F.; Bouchard, C.; Aoussat, A. Integration of Environmental Assessment in a PLM Context: A Case Study in Luxury Industry. In Product Lifecycle Management for a Global Market. PLM 2014. IFIP Advances in Information and Communication Technology; Fukuda, S., Bernard, A., Gurumoorthy, B., Bouras, A., Eds.; Springer: Berlin/Heidelberg, Germany, 2014; Volume 442.

63. Gmelin, H.; Seuring, S. Determinants of a sustainable new product development. J. Clean. Prod. 2014, 69, 1-9. [CrossRef]

64. Ahmad, S.; Wong, K.Y.; Tseng, M.L.; Wong, W.P. Sustainable product design and development: A review of tools, applications and research prospects. Resour. Conserv. Recycl. 2018, 132, 49-61. [CrossRef]

65. Yang, C.J.; Chen, J.L. Accelerating preliminary eco-innovation design for products that integrates case-based reasoning and TRIZ method. J. Clean. Prod. 2011, 19, 998-1006. [CrossRef]

66. Romli, A.; Setchi, R.; Prickett, P.; de la Pisa, M.P. Eco-design case-based reasoning tool: The integration of ecological quality function deployment and case-based reasoning methods for supporting sustainable product design. Proc. Inst. Mech. Eng. Part B J. Eng. Manuf. 2016, 232, 1778-1797. [CrossRef]

67. Kolodner, J.L. An Introduction to Case-Based Reasoning. Artif. Intell. Rev. 1992, 6, 3-34. [CrossRef]

68. Germani, M.; Mandolini, M.; Marconi, M.; Morbidoni, A.; Rossi, M. A Case-Based Reasoning Approach to Support the Application of the Eco-Design Guidelines. In Proceedings of the 20th CIRP International Conference on Life Cycle Engineering, Singapore, 17-19 April 2013.

69. Vargas Hernandez, N.; Okudan Kremer, G.; Schmidt, L.C.; Acosta Herrera, P.R. Development of an expert system to aid engineers in the selection of design for environment methods and tools. Expert Syst. Appl. 2012, 39, 9543-9553. [CrossRef]

70. Rossi, M.; Germani, M.; Zamagni, A. Review of ecodesign methods and tools. Barriers and strategies for an effective implementation in industrial companies. J. Clean. Prod. 2016, 129, 361-373. [CrossRef]

71. Moreno, M.; Ponte, O.; Charnley, F. A Taxonomy of design strategies for a circular design tool. In Proceedings of the 2nd Conference on Product Lifetimes and the Environment, Delft, The Netherlands, 8-10 November 2017; pp. 275-279.

72. Salari, M.; Bhuiyan, N. A new model of sustainable product development process for making trade-offs. Int. J. Adv. Manuf. Technol. 2016, 94, 1-11. [CrossRef]

73. Chiu, M.C.; Kremer, G.E.O. Investigation of the applicability of Design for $\mathrm{X}$ tools during design concept evolution: A literature review. Int. J. Prod. Dev. 2011, 13, 132-167. [CrossRef]

74. Kjaer, L.L.; Pigosso, D.C.A.; McAloone, T.C.; Birkved, M. Guidelines for evaluating the environmental performance of Product/Service-Systems through life cycle assessment. J. Clean. Prod. 2018, 190, 666-678. [CrossRef] 
75. Selvefors, A.; Strömberg, H.; Renström, S. What a designer can change: A proposal for a categorisation of artefact-related aspects. In Proceedings of the 2016 Design Research Society 50th Anniversary Conferance, Brighton, UK, 27-30 June 2016; pp. 1-17.

76. Kuzmina, K.; Prendeville, S.; Walker, D.; Charnley, F. Future scenarios for fast-moving consumer goods in a circular economy. Futures 2019, 107, 74-88. [CrossRef]

77. Charnley, F.; Walker, D.; Kuzmina, K. Fast-Moving Circular Goods 2025; The Nexus Network: Brighton, UK, 2015.

78. Haffmans, S.; van Gelder, M.; Van Hinte, E.; Zijlstra, Y. Products that Flow: Circular Business Models and Design Strategies for Fast-Moving Consumer Goods; BIS Publisher: Amsterdam, The Netherlands, 2018.

(C) 2020 by the authors. Licensee MDPI, Basel, Switzerland. This article is an open access article distributed under the terms and conditions of the Creative Commons Attribution (CC BY) license (http://creativecommons.org/licenses/by/4.0/). 